\title{
Modeling the impediment of methane ebullition bubbles by seasonal lake ice
}

\author{
S. Greene ${ }^{1}$, K. M. Walter Anthony ${ }^{2}$, D. Archer ${ }^{3}$, A. Sepulveda-Jauregui ${ }^{2}$, and K. Martinez-Cruz ${ }^{2,4}$ \\ ${ }^{1}$ Department of Chemistry, the University of Chicago, Chicago, Illinois, USA \\ ${ }^{2}$ Water and Environmental Research Center, Institute of Northern Engineering, \\ University of Alaska Fairbanks, Fairbanks, Alaska, USA \\ ${ }^{3}$ Department of the Geophysical Sciences, the University of Chicago, Chicago, Illinois, USA \\ ${ }^{4}$ Biotechnology and Bioengineering Department, Cinvestav, Mexico City, D. F., Mexico \\ Correspondence to: K. M. Walter Anthony (kmwalteranthony@alaska.edu)
}

Received: 13 June 2014 - Published in Biogeosciences Discuss.: 15 July 2014

Revised: 23 September 2014 - Accepted: 19 October 2014 - Published: 8 December 2014

\begin{abstract}
Microbial methane $\left(\mathrm{CH}_{4}\right)$ ebullition (bubbling) from anoxic lake sediments comprises a globally significant flux to the atmosphere, but ebullition bubbles in temperate and polar lakes can be trapped by winter ice cover and later released during spring thaw. This "ice-bubble storage" (IBS) constitutes a novel mode of $\mathrm{CH}_{4}$ emission. Before bubbles are encapsulated by downward-growing ice, some of their $\mathrm{CH}_{4}$ dissolves into the lake water, where it may be subject to oxidation. We present field characterization and a model of the annual $\mathrm{CH}_{4}$ cycle in Goldstream Lake, a thermokarst (thaw) lake in interior Alaska. We find that summertime ebullition dominates annual $\mathrm{CH}_{4}$ emissions to the atmosphere. Eighty percent of $\mathrm{CH}_{4}$ in bubbles trapped by ice dissolves into the lake water column in winter, and about half of that is oxidized. The ice growth rate and the magnitude of the $\mathrm{CH}_{4}$ ebullition flux are important controlling factors of bubble dissolution. Seven percent of annual ebullition $\mathrm{CH}_{4}$ is trapped as IBS and later emitted as ice melts. In a future warmer climate, there will likely be less seasonal ice cover, less IBS, less $\mathrm{CH}_{4}$ dissolution from trapped bubbles, and greater $\mathrm{CH}_{4}$ emissions from northern lakes.
\end{abstract}

\section{Introduction}

Globally, the magnitude of methane $\left(\mathrm{CH}_{4}\right)$ emissions from freshwater lakes (72 $\mathrm{Tg} \mathrm{CH}_{4} \mathrm{yr}^{-1}$; Bastviken et al., 2011) constitutes an estimated $30 \%$ of all natural emissions (217 $\mathrm{Tg} \mathrm{CH}_{4} \mathrm{yr}^{-1}$; IPCC, 2013). Methane is typically pro- duced in anoxic bottom sediments by methanogenic microbes and can be released to the atmosphere by diffusion, vascular transport through aquatic plants, or ebullition (bubbling) (Rudd and Hamilton, 1978; Bastviken et al., 2004; Whalen, 2005). Methanogenesis in the oxic water column has been proposed as an additional $\mathrm{CH}_{4}$ source in some lakes (Tang et al., 2014). In many lakes, ebullition from bottom sediments is the dominant mode of emission because gasphase $\mathrm{CH}_{4}$ in bubbles is not subject to oxidation, whereas a significant proportion of dissolved $\mathrm{CH}_{4}$ is typically oxidized by methanotrophic bacteria, including in the plant rhizosphere (Keller and Stallard, 1994; Casper et al., 2000; Bastviken et al., 2008).

Most ebullition $\mathrm{CH}_{4}$ in shallow lakes is released directly to the atmosphere in the summer, but in cold-climate regions bubbles are trapped beneath and encapsulated by downwardgrowing lake ice in the winter (Walter et al., 2006). Methane involved in this "ice-bubble storage" (IBS) is later released during spring thaw. The $\mathrm{CH}_{4}$ content of bubbles decreases as they are encapsulated, which suggests $\mathrm{CH}_{4}$ dissolution into the water column (Walter et al., 2008). Dissolved $\mathrm{CH}_{4}$ accumulates in many lakes during the ice-cover period due to the slowdown or inactivity of methanotrophs in the cold, often anoxic water column (Michmerhuizen et al., 1996; Phelps et al., 1998; Boereboom et al., 2012), so dissolved $\mathrm{CH}_{4}$ from bubbles may not be immediately subject to oxidation. However, it can potentially be oxidized when oxygen is reintroduced during spring ice melt. The fraction of $\mathrm{CH}_{4}$ that escapes to the atmosphere from seasonally ice-covered 
lakes depends on these biogeochemical processes. Previously, Sasaki et al. (2009) measured the $\mathrm{CH}_{4}$ concentration of bubbles trapped within lake ice in Antarctica and used aerial imaging to estimate the total volume of gas trapped before the ice melts. Elsewhere, others have measured dissolved $\mathrm{CH}_{4}$ concentrations beneath winter lake ice or the $\mathrm{CH}_{4}$ diffusion rate following ice-off to estimate net springtime emissions (e.g., Michmerhuizen et al., 1996; Phelps et al., 1998; Smith and Lewis, 1992).

In northern Siberian thermokarst (thaw) lakes, ebullition occurs mainly at discrete locations ("seeps") on the lake bottom (Walter et al., 2006). Bubbles trapped within the ice above seeps (at "seep sites") are easily visible in early-winter lake ice (Fig. 1a). Walter et al. (2006) defined four classes of seeps: A, B, C, and Hotspot (Fig. 1b). A-type seeps exhibit lower ebullition rates and a greater degree of separation among ice-trapped bubbles; B- and C-type seeps exhibit progressively higher ebullition rates and greater degrees of bubble coalescence in ice. Ebullition rates are highest for Hotspots, where frequent bubbling brings warmer water from the lake bottom to the surface, maintaining open water during a portion of the ice-cover period. When air temperatures are sufficiently cold, a thin layer of ice covers Hotspot seep sites, beneath which gas accumulates in a cavity open to the water column. Using submerged bubble traps placed above seeps to measure short- and long-term (year-round) seepclass ebullition rates and counts of ebullition seep sites in lake-ice transects, Walter Anthony and Anthony (2013) estimated whole-lake seep ebullition. Translating seep ebullition to atmospheric $\mathrm{CH}_{4}$ emission from seeps was not possible due to a lack of knowledge about the degree to which seasonal lake ice reduces ebullition emissions.

This manuscript describes the formulation of a model, informed by field measurements, of $\mathrm{CH}_{4}$ dissolution from trapped ebullition bubbles in Goldstream Lake, a thermokarst lake in interior Alaska. This study has three goals: (1) to gain insight into how some physical and biogeochemical processes within a thermokarst lake interact to determine seasonal and annual $\mathrm{CH}_{4}$ emissions via diffusion, ebullition, and IBS; (2) to determine the extent to which lake ice reduces net annual emissions; and (3) to gain insight into how changes in climate will influence emissions by different modes in the future.

\section{Methods}

\subsection{Study site}

Goldstream Lake (informal name; $64.92^{\circ} \mathrm{N}, 147.85^{\circ} \mathrm{W}$; area $10030 \mathrm{~m}^{2}$; volume $15700 \mathrm{~m}^{3}$; mean depth $1.6 \mathrm{~m}$; max depth $2.9 \mathrm{~m}$ ) is located near the bottom of Goldstream Valley in the discontinuous permafrost zone of interior Alaska. The lake formed by the melting of permafrost ground ice in retransported late-Quaternary loess common on many hill a)

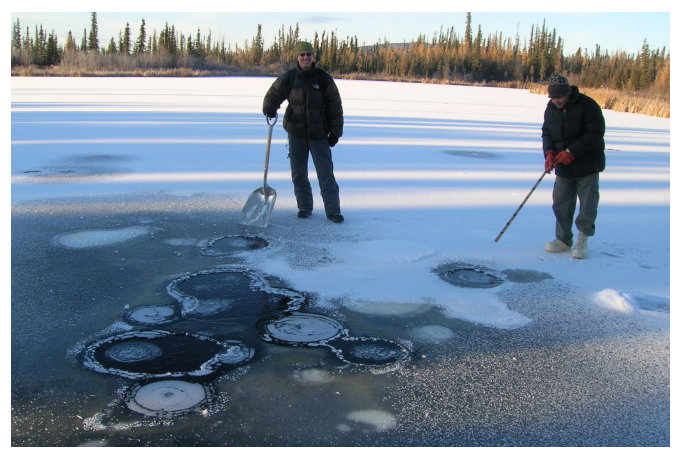

b)
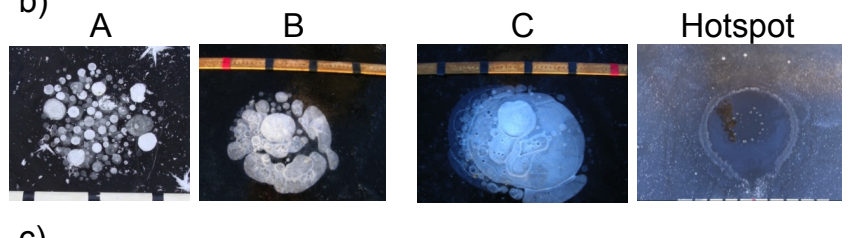

c)
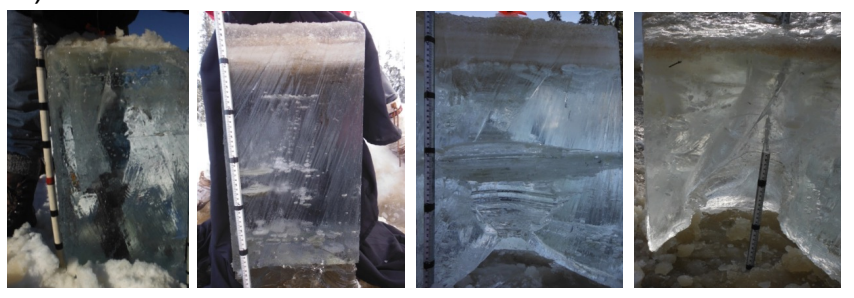

Figure 1. (a) Photograph showing $\mathrm{CH}_{4}$-rich bubbles trapped by ice at Goldstream Lake in mid-October 2007. (b) Photographs of representative A-, B-, C-, and Hotspot-type seep sites as seen from above in early-winter lake ice. Note the open water at the Hotspot seep site. The black and red markings on the rulers shown are $10 \mathrm{~cm}$ apart. (c) Side-view photographs of blocks of ice harvested from above seep sites in spring. Note the hollow cavity in the block harvested from above the Hotspot seep site (at right).

slopes and valley bottoms of interior Alaska (Muhs and Budahn, 2006). Colluvial forces and frost action gradually eroded loess downslope during the late Pleistocene and early Holocene, forming icy, organic-rich deposits known as "yedoma", frequently several tens of meters deep in valley bottoms (Péwé, 1975; Muhs and Budahn, 2006; Reyes et al., 2010; Kanevskiy et al., 2011). Ice wedges 2 to $4 \mathrm{~m}$ wide at their tops and up to tens of meters deep are common in this type of permafrost (Hamilton et al., 1988). Ground-ice melt leads to collapse of the surface and ground subsidence, a process known as thermokarst (Mackay, 1970). Ponding of water in depressions further accelerates permafrost thaw, leading to expansion and deepening of thermokarst lakes over time. Remote-sensing observations of Goldstream Lake showed that a partial drainage event occurred in the lake sometime after 1949; however, thermokarst expansion continues today, predominantly along its eastern margin (the "thermokarst zone", Fig. 2). Walter Anthony and Anthony (2013) observed higher ebullition activity within this zone (i.e., a greater density of seeps, particularly high-flux 


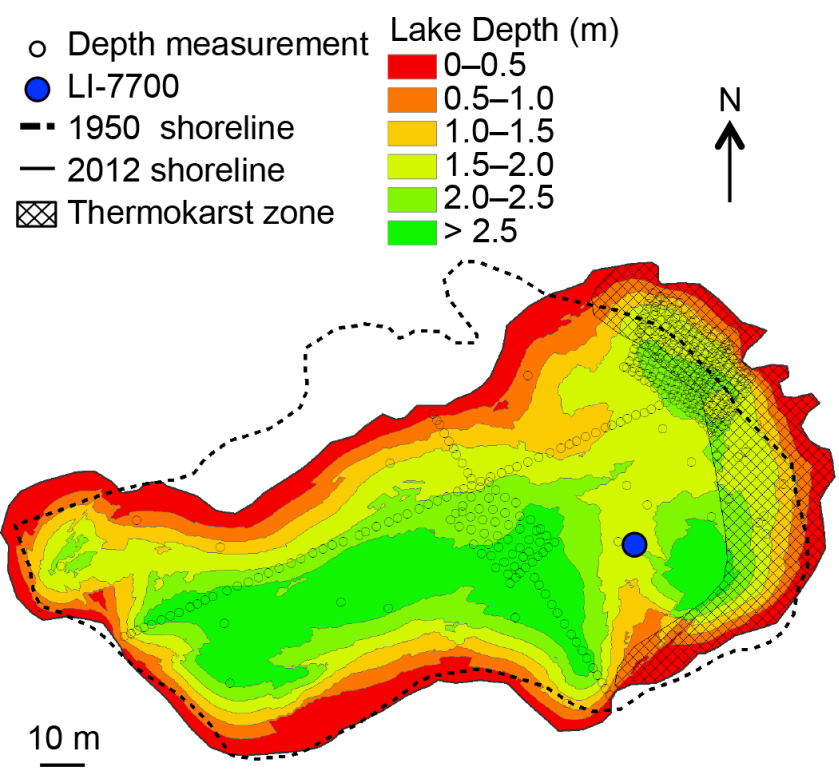

Figure 2. Map of Goldstream Lake showing the location of the LI7700 Open Path Methane Analyzer used to measure atmospheric $\mathrm{CH}_{4}$ concentrations, locations of depth measurements, $0.5 \mathrm{~m}$ bathymetric isolines, shoreline locations in 2012 and 1950, and the thermokarst zone, characterized by eastward thermokarst expansion and high ebullition activity.

Hotspot seeps) than in the remainder of the lake (the "nonthermokarst zone").

\subsection{Field observations}

\subsubsection{Lake bathymetry}

During the winter of 2011-2012, we mapped the bathymetry of Goldstream Lake using sonar point measurements (Vexilar LPS-1 Handheld Depth sounder, Minneapolis, Minnesota, USA) through ice or in ice-augered holes combined with centimeter-accuracy RTK differential GPS (Leica Geosystems AG, Heerbrugg, Switzerland) at 99 distributed locations on the lake. In late October 2011, depth measurements were obtained using sonar through ice at 347 points within two rectangular plots in the lake center and northeast thermokarst zone at a density of approximately 0.22 measurements per square meter. We produced an interpolated bathymetric map using kriging in ArcGIS (Esri, Redlands, California, USA). The resulting map was used to create a three-dimensional model of the lake in ArcScene (Esri), from which we estimated the water volume in $0.5 \mathrm{~m}$ depth intervals relative to the water level on 30 October 2011, the date of $>95 \%$ of bathymetry measurements.

\subsubsection{Water level}

Measurements of hydrostatic pressure at the bottom of Goldstream Lake (Global Water WL 16 vented submersible pres- sure transducer with a Global Logger v2.1.4 data logger, College Station, Texas, USA) were used to estimate changes in the lake's water level and volume throughout the study period. We define the water level during the ice-cover period as the height of the water column at the measurement site if, hypothetically, all of the snow and ice on the lake surface melted. Hydrostatic pressure measurements were not available from 21 May 2011 to 14 February 2012 and on several dates in the fall of 2012. From 12 October 2011 to 14 February 2012, we used daily precipitation measurements (Sect. 2.2.8) to extrapolate the water level backward from 14 February 2012. The water level from 21 May 2011 to 11 October 2011 and on dates in the fall of 2012 was linearly interpolated between adjacent values (Appendix Fig. B1).

\subsubsection{Water temperature}

Temperature-depth profiles were obtained within Goldstream Lake between 19 October 2010 and 2 July 2012 using a handheld Hach DS5 Multiprobe Sonde (Hach Hydromet, Loveland, Colorado, USA). Measurements were obtained at approximately five depths at each of two sites on each sampling day. Additionally, we measured water column temperatures at depth intervals of $0.5 \mathrm{~m}$ from the lake surface hourly from 10 April 2009 through 8 December 2013 using HOBO Water Temperature/Light pendant loggers (Onset, Bourne, Massachusetts, USA). One logger was located near the center of Goldstream Lake and another in the thermokarst zone.

\subsubsection{Lake ice types and phenology}

Congelation (black) ice is formed when water freezes at the bottom of the ice layer and therefore appears clear. In contrast, snow (white) ice is opaque and is formed when the weight of snow depresses the ice surface beneath the water level, causing lake water to flood snow on top of the ice layer and freeze. During the ice-cover seasons from October 2010 to May 2012, we obtained the thicknesses of each type of ice, as well as that of snow, by augering a hole in the ice $(20 \mathrm{~cm}$ diameter) near the lake center, measuring the total ice and snow thicknesses around the auger hole, and looking through the hole for differences in ice color to estimate white and black ice thicknesses with a measuring tape. In the winter of 2010-2011, measurements were made where snow was occasionally compacted by foot traffic; measurements in 2011-2012 were made in undisturbed locations. Using a time-lapse camera (Game Spy I-60, Moultrie, Alabaster, Alabama, USA), we acquired images of the lake surface every $4 \mathrm{~h}$ from 16 April 2010 to 14 May 2010 to constrain the timing of freeze-up and ice-off (the first and last days of any observed ice cover, respectively).

\subsubsection{Water column dissolved gases}

Dissolved $\mathrm{CH}_{4}$ concentration-depth profiles were measured in the center of Goldstream Lake and $5 \mathrm{~m}$ away from the 
eastern shore on 34 days between 27 October 2010 and 22 September 2012. Duplicate water samples were collected from a boat in summer or from the lake ice surface through an auger hole in winter. Water samples $(10 \mathrm{~mL})$ collected with a Van Dorn bottle (Wildco, Yulee, Florida, USA) were gently transferred into $25 \mathrm{~mL}$ glass serum bottles and immediately sealed with butyl rubber stoppers and aluminum crimp caps. Bottles were stored upside down and frozen in the dark until laboratory analysis. We thawed samples overnight in the refrigerator, brought them to room temperature for $10 \mathrm{~min}$, and shook them for $15 \mathrm{~s}$ to equilibrate headspace and water. We then measured the $\mathrm{CH}_{4}$ concentration in the headspace using a GC-2014 gas chromatograph (Shimadzu, Addison, Illinois, USA) equipped with a flame ionization detector and a PLOT (porous layer open tubular) alumina column (detector temperature $250^{\circ} \mathrm{C}$, oven $40^{\circ} \mathrm{C}$, high-purity helium as carrier gas). Dissolved $\mathrm{CH}_{4}$ concentrations were calculated from headspace $\mathrm{CH}_{4}$ concentrations using a temperaturedependent Henry's law constant (Wilhelm et al., 1977).

Dissolved oxygen $\left(\mathrm{O}_{2}\right)$ concentrations were measured simultaneously with water temperature using a Clark-type microelectrode on the calibrated Hach DS5 Multiprobe Sonde (Sect. 2.2.3).

Measured concentrations were used to estimate total amounts of $\mathrm{CH}_{4}$ and $\mathrm{O}_{2}$ dissolved in Goldstream Lake. To facilitate comparison with our model, interpolated concentration profiles were integrated with respect to depth using bathymetry measurements to calculate total quantities of dissolved gas separately in the upper $1.25 \mathrm{~m}$ of the water column and in the lower layer (below $1.25 \mathrm{~m}$ ). The volume of the upper layer was adjusted to account for changes in the ice/snow layer thickness, calculated using our ice growth model (Sect. 2.3.2).

\subsubsection{Ebullition}

Seep ebullition in Goldstream Lake was characterized using methods described previously by Walter Anthony et al. (2010). We used average areal densities (seeps $\mathrm{m}^{-2}$ ) for each class measured by Walter Anthony and Anthony (2013) in transects covering $11 \%$ of Goldstream Lake, plus another, subsequent $428 \mathrm{~m}^{2}$ survey plot that increased the total area of the lake surveyed for A-, B-, and C-type seeps to $15 \%$. The entire lake surface was surveyed for Hotspot seeps. The resulting seep densities (A: 0.31 seeps $\mathrm{m}^{-2}$; B: 0.08 seeps $\mathrm{m}^{-2}$; C: 0.03 seeps $\mathrm{m}^{-2}$; and Hotspot: 0.01 seeps $\mathrm{m}^{-2}$ ) were used as inputs to the model.

Seep-class-specific smoothed ebullition rates $(\mathrm{mL}$ gas seep ${ }^{-1} \mathrm{~d}^{-1}$ ), indexed by Julian day, were applied to all seeps in the model. These were calculated from long-term (up to 700 days) measurements of daily ebullition rates for 31 seeps in four Arctic thermokarst lakes (Walter Anthony et al., 2010). Twelve of these seeps were located in Goldstream Lake, and average bubbling rates for each class of seeps in Goldstream Lake were not significantly different from the Arctic averages. We calculated the mean ebullition rate on each Julian day for each class from our measurements of individual seeps. Because ebullition from individual seeps is often highly episodic, and because there were significant data collection gaps for many seeps, resulting in certain $\mathrm{Ju}-$ lian days on which only a few seeps were represented in the average, the resulting annual flux cycle represented by Julian day averages was highly irregular. We smoothed Julian day averages three times by taking 30-day running averages of daily averages in order to remove these irregularities, as we wanted these smoothed data to represent the annual ebullition cycle rather than the ebullition dynamics of individual seeps. This smoothing did not change the total calculated yearly amount of $\mathrm{CH}_{4}$ released from seeps by ebullition.

For comparison with smoothed fluxes in a sensitivity analysis of the model, we also used measured fluxes from individual seeps with relatively few data gaps, which were scaled and applied to the 2010-2012 study period. In the sensitivity analysis, we included measurements of nine A-type seeps, seven B-type seeps, five C-type seeps, and seven Hotspots in Goldstream Lake, Cranberry Lake (interior Alaska), Shuchi Lake (Siberia), and Grass Lake (Siberia) year-round during 1 or more years between 2003 and 2014. All of these lakes are thermokarst lakes that formed in yedoma-type permafrost deposits. Smoothed and individual seep fluxes are presented in Fig. 3.

During the period of decreasing ice thickness in the spring (the "ice-melt period"), when standing water was present on the ice surface, we observed gas escaping from bubbles trapped by the ice. On 18 April 2010 and 21 April 2011, we collected such gas from eight ice-trapped bubbles in Goldstream Lake, four of which were located above the same ebullition seep. Gas was collected by displacement into inverted, water-filled glass serum bottles, which were then sealed with butyl rubber stoppers and aluminum crimp caps until later analysis. Additionally, bubbles from 246 ebullition events in Goldstream Lake were collected from submerged bubble traps above ebullition seeps from 2008 to 2011 following methods described by Walter et al. (2008). These "fresh" samples enabled us to calculate the $\mathrm{CH}_{4}$ composition of bubbles after they ascend through the water column but before they interact with lake ice, allowing for the conversion of measured volumetric fluxes ( $\mathrm{ml}$ gas seep ${ }^{-1} \mathrm{~d}^{-1}$ ) to molar fluxes ( $\mathrm{mol} \mathrm{CH}_{4} \mathrm{seep}^{-1} \mathrm{~d}^{-1}$ ). All samples were transported to the lab and stored under refrigeration, in the dark. The $\mathrm{CH}_{4}$ concentrations of samples were analyzed using the Shimadzu GC-2014 gas chromatograph.

Additionally, blocks of ice were harvested from ebullition seep sites with a chainsaw in the late winter and early spring, and the shapes of encapsulated bubbles and cavities within ice blocks were measured (Fig. 1c). 
a)
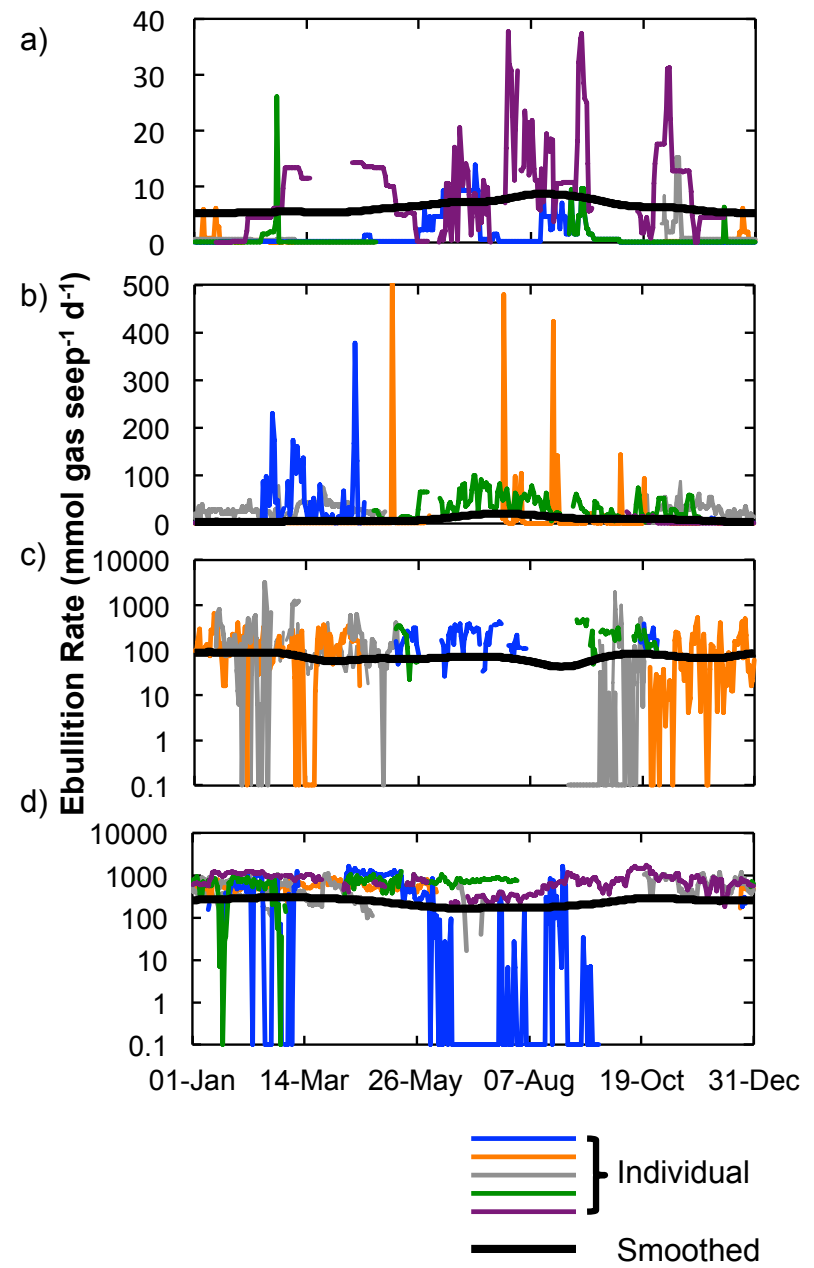

Figure 3. Time-smoothed daily ebullition rates, and rates for individually measured seeps as applied in the model, for A-, B-, C-, and Hotspot-type seeps (panels $\mathbf{a}, \mathbf{b}, \mathbf{c}, \mathbf{d}$ ). Note the difference in scales on $y$ axes, including the $\log$ scale in panels $\mathbf{c}$ and $\mathbf{d}$.

\subsubsection{Ice-bubble mesocosms}

Measurements of the rate of $\mathrm{CH}_{4}$ diffusion from submerged, gas-filled mesocosm chambers constrained our model of diffusion from trapped bubbles. During each of two trials (spring and fall, 19-24 April 2011 and 30 October-6 November 2011), we suspended 24 chambers approximately $14 \mathrm{~cm}$ below the water surface in random positions within two $1 \mathrm{~m}$ by $3 \mathrm{~m}$ holes opened in the ice near the center of Goldstream Lake. The observation of relatively few ice-trapped bubbles in bubble transect surveys in the lake's center suggests that rates of natural ebullition from the sediments are relatively low there. Mesocosm chambers consisted of inverted containers $(14 \mathrm{~cm}$ by $14 \mathrm{~cm}$ by $25 \mathrm{~cm}$ tall; Tupperware, Orlando, Florida, USA) filled with lake water and fitted with a three-way stopcock to release gas. A gas standard $(140 \mathrm{~mL})$ with a composition similar to that of natural seep ebullition bubbles $\left(80 \% \mathrm{CH}_{4}, 20 \% \mathrm{~N}_{2}\right)$ was then injected such that its height within each chamber (ca. $10 \mathrm{~mm}$ ) approximated the measured thickness of small bubbles trapped beneath ice $(5.7 \pm 1.0 \mathrm{~mm}$, mean \pm standard deviation). Chambers were open to lake water but fitted with deflectors beneath to deter natural ebullition bubbles from entering. At 1-day intervals (including a time zero control), we recovered gas from triplicate chambers and measured its volume and $\mathrm{CH}_{4}$ composition. Regrowth of lake ice above the chambers did not reach $14 \mathrm{~cm}$, so no chambers became surrounded by ice.

The following equation, which is based on Fick's first law in one dimension, gives the $\mathrm{CH}_{4}$ dissolution flux, $J$, from chambers (Holocher et al., 2003):

$J=D_{\mathrm{CH}_{4}} \frac{\left[\mathrm{CH}_{4}\right]_{\mathrm{eq}}-\left[\mathrm{CH}_{4}\right]}{\delta_{\text {eff }}}$,

where $D_{\mathrm{CH}_{4}}$ is the diffusivity of $\mathrm{CH}_{4}$ in water $\left(0.98 \times 10^{-9} \mathrm{~m}^{2} \mathrm{~s}^{-1}\right.$; Broecker and Peng, 1974), and $\left[\mathrm{CH}_{4}\right]_{\text {eq }}$ and $\left[\mathrm{CH}_{4}\right]$ are the equilibrium and bulk concentrations of dissolved $\mathrm{CH}_{4}$ in lake water. $\delta_{\text {eff }}$ represents an effective diffusively controlled layer thickness, calibrated such that the gradient calculated from $\left[\mathrm{CH}_{4}\right]_{\mathrm{eq}},\left[\mathrm{CH}_{4}\right]$, and $\delta_{\text {eff }}$ equals the true gradient at the bubble's surface. The $\mathrm{CH}_{4}$ mole fraction determines $\left[\mathrm{CH}_{4}\right]_{\text {eq }}$, based on the hydrostatic pressure in the chamber and a Henry's law constant of $2.533 \times 10^{-5} \mathrm{~mol} \mathrm{~L}^{-1} \mathrm{kPa}^{-1}$ for $\mathrm{CH}_{4}$ in water at $0{ }^{\circ} \mathrm{C}$ (Yamamoto et al., 1976). The bulk $\mathrm{CH}_{4}$ concentration was taken to be the average concentration in the upper $1.25 \mathrm{~m}$ of the water column, calculated from measurements (Sect. 2.2.5).

A simple model based on Eq. (1) with a $1 \mathrm{~h}$ time step was used to simulate $\mathrm{CH}_{4}$ dissolution from chambers. For each trial, $\delta_{\text {eff }}$ was calibrated to optimize the fit between the modeled and measured $\mathrm{CH}_{4}$ composition and volume. The exchange of other gases between chambers and the water column was neglected, as we estimated that including $\mathrm{N}_{2}$ exchange has a negligible (ca. $7 \%$ ) effect on the magnitude of $\mathrm{CH}_{4}$ dissolution. This model exhibited close fits to measurements at the optimum values of $\delta_{\text {eff }}(0.25$ and $0.27 \mathrm{~mm}$ for the spring and fall trials, respectively, Fig. 4). Because $\delta_{\text {eff }}$ values were fairly consistent between trials, which were conducted in conditions with substantially different upper-layer $\mathrm{CH}_{4}$ concentrations (290 and $2 \mu \mathrm{M}$ in spring and fall trials, respectively), we applied this formula with a $\delta_{\text {eff }}$ of $0.26 \mathrm{~mm}$ in our model of $\mathrm{CH}_{4}$ diffusion from trapped ebullition bubbles (Sect. 2.3.3).

\subsubsection{Meteorological observations}

Daily measurements of maximum and minimum air temperature, barometric pressure, precipitation, wind velocity, and snow depth were obtained from a US National Weather Service (NWS) Cooperative Observer Program site located approximately $2.6 \mathrm{~km}$ southwest of Goldstream Lake. 


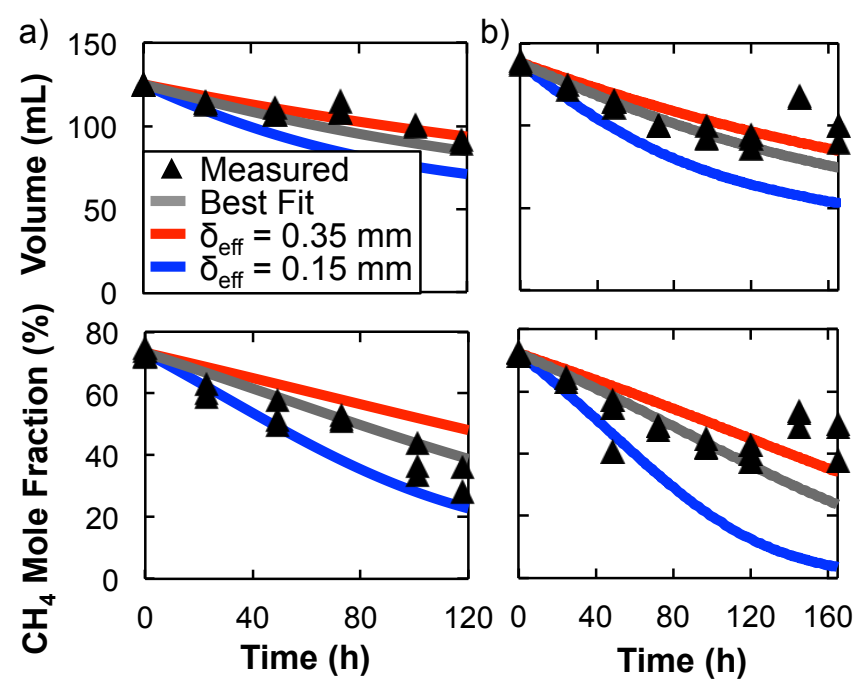

Figure 4. Modeled and measured volume and $\mathrm{CH}_{4}$ mole fraction of gas inside ice-bubble mesocosm chambers in the spring 2011 (a) and fall 2011 (b) trials. Values of $\delta_{\text {eff }}=0.25$ and $0.27 \mathrm{~mm}$ were found to give the best fits to volume and composition measurements for the spring and fall trials, respectively. Values of $\delta_{\text {eff }}=0.35$ and $0.15 \mathrm{~mm}$ encompassed the range of uncertainty in these measurements, so they were used in sensitivity analyses (Sect. A3).

Minimum and maximum temperatures were averaged to calculate daily mean temperatures.

\subsubsection{Atmospheric $\mathrm{CH}_{4}$ concentrations}

We monitored the concentration of atmospheric $\mathrm{CH}_{4} 50 \mathrm{~cm}$ above the lake surface from 12 April 2010 to 9 May 2011 using a LI-7700 Open Path Methane Analyzer (LI-COR Biosciences, Lincoln, Nebraska, USA) mounted on a stationary raft. The radius of its concentration measurement footprint was approximately $60 \mathrm{~m}$ (area $10,600 \mathrm{~m}^{2}$; Gash, 1986). The lake surface occupied the majority of the footprint; however, littoral vegetation and black spruce forest-tundra occupied approximately $30 \%$ of the footprint, primarily in the southeastern quadrant (Fig. 2). The prevailing wind direction in Goldstream Valley from 2008 to 2013 was from the $\mathrm{N}$ in summer and from the NNE the remainder of the year; thus the terrestrial contribution to the LI-7700 signal should have been minimal. Measurements of atmospheric $\mathrm{CH}_{4}$ concentration were obtained five times per second and converted to daily averages.

\subsubsection{Methane diffusion from sediments}

We calculated the rate of $\mathrm{CH}_{4}$ diffusion into the water column from $\mathrm{CH}_{4}$-rich lake bottom sediments using measurements of $\mathrm{CH}_{4}$ concentrations in the surface sediments of Vault Lake, a thermokarst lake near Goldstream Lake, because measurements from Goldstream Lake were unavailable. Since Vault Lake formed in similar yedoma-type per- mafrost deposits, we assumed that sediment concentrations from Vault Lake were representative of Goldstream Lake. We obtained two sediment cores in March 2013 from a location in between the center and active thermokarst margin of Vault Lake and kept the cores under refrigeration at $2{ }^{\circ} \mathrm{C}$ prior to laboratory analysis. Triplicate samples $(5 \mathrm{~mL}$ each $)$ were obtained with a syringe at multiple depths within the top $5 \mathrm{~cm}$ of the cores and transferred to $20 \mathrm{~mL}$ serum vials containing $10 \mathrm{~mL}$ of $\mathrm{CH}_{4}$-free water. Vials were sealed with rubber caps. The $\mathrm{CH}_{4}$ concentration in the water was determined using methods described previously in Sect. 2.2.5 and converted to a $\mathrm{CH}_{4}$ concentration per unit sediment volume. This was converted to a concentration per unit water volume using measurements of sediment density in Vault Lake (K. M. Walter Anthony, unpublished data). The resulting concentration gradient between the topmost two measurements was multiplied by the molecular diffusivity of $\mathrm{CH}_{4}$ to calculate the diffusive flux according to Fick's first law.

The methanogenic rate in lake sediments varies with temperature (Schulz et al., 1997; Sepulveda-Jauregui et al., 2014a). In order to quantify this effect on sediment diffusion rates in the model, we monitored the temperature of surface sediments in Goldstream Lake from 3 July 2008 to 23 March 2012 using the HOBO temperature loggers (Sect. 2.2.3). On days during the study period when temperature measurements were available, we applied the average temperature from both measurement locations in the model; when temperature measurements were unavailable, we used Julian day temperature averages calculated from data from the entire measurement period. We used a $Q_{10}$ value for methanogenesis of 2.4 from Kelly and Chynoweth (1981) to scale the average diffusive flux calculated from both sediment cores from Vault Lake on each day of the study period, depending on the sediment temperature in Goldstream Lake. We assumed that the diffusive flux calculated from measurements was representative of the in situ diffusive flux at $2{ }^{\circ} \mathrm{C}$, the temperature of the cores before analysis. Calculated daily fluxes are shown in Fig. B2. We acknowledge that there is uncertainty in our calculated sediment diffusion rate for the following reasons: (1) in reality, a greater rate of methanogenesis in surface sediments may correspond to a greater proportion of $\mathrm{CH}_{4}$ escaping via ebullition instead of diffusion; the rate of methanogenesis may scale differently than the rate of diffusion as temperature varies. (2) The diffusive flux of $\mathrm{CH}_{4}$ is usually very variable across the lake bottom, and our calculations for Goldstream Lake are based on the average flux calculated from only two cores from Vault Lake.

\subsection{Modeling}

\subsubsection{Overview}

Our model simulates the processes that influence $\mathrm{CH}_{4}$ transport through Goldstream Lake during the 2-year period in which primary field measurements were collected. Bubbles, 
released from seeps as observed (Sect. 2.2.6), are either trapped beneath lake ice or released to the atmosphere. Some $\mathrm{CH}_{4}$ dissolves out of bubbles before they are encapsulated by growing ice. The model water column is resolved into two layers ("upper" and "lower"), divided at $1.25 \mathrm{~m}$ below the lake surface, because measured $\mathrm{CH}_{4}$ concentrations varied independently in these layers during spring ice-melt periods. Changes in the amount of dissolved $\mathrm{CH}_{4}$ in the lake's water column were driven by dissolution from bubbles trapped beneath ice, aerobic methanotrophy, atmospheric $\mathrm{CH}_{4}$ emission from freezing water on the ice surface during winter "flooding events" (Sect. 2.3.2), dissolved $\mathrm{CH}_{4}$ diffusion to the atmosphere in spring and summer, and lake overturn events. $\mathrm{CH}_{4}$ diffused into the lower layer of the water column from sediments at a constant rate determined from measurements (Sect. 2.2.10).

\subsubsection{Ice growth}

The rate of black ice growth, which determines how quickly bubbles become encapsulated, is calculated based on a diffusive energy balance model from the steady-state temperature profile through snow and ice on the lake surface. Setting the surface temperature to the observed air temperature and the temperature at the ice-water interface to $0^{\circ} \mathrm{C}$ yields the following formula for the daily change in black ice thickness:

$\Delta z_{\mathrm{b}}=\alpha^{2} \frac{\Delta t}{\rho_{i} \Delta \mathrm{H}_{\text {fus }}} \times \frac{0^{\circ} \mathrm{C}-T_{\mathrm{air}}}{\frac{z_{\mathrm{b}}}{k_{\mathrm{i}}}+\frac{z_{\mathrm{w}}}{k_{\mathrm{i}}}+\frac{z_{\mathrm{s}}}{k_{\mathrm{s}}}}$,

where $\Delta t$ is $1 \mathrm{~d}$; $\rho_{i}$ is the ice density $\left(913 \mathrm{~kg} \mathrm{~m}^{-3}\right.$; Duguay et al., 2003); $\Delta \mathrm{H}_{\text {fus }}$ is the enthalpy of fusion for water $\left(334 \mathrm{~J} \mathrm{~g}^{-1}\right) ; T_{\text {air }}$ is the mean daily air temperature; $z_{\mathrm{b}}, z_{\mathrm{w}}$, and $z_{\mathrm{s}}$ are the thicknesses of black ice, white ice, and snow, respectively; and $k_{\mathrm{i}}$ and $k_{\mathrm{S}}$ are the thermal conductivities of ice (2.034 $\mathrm{W} \mathrm{m}^{-1} \mathrm{~K}^{-1}$; Duguay et al., 2003) and of snow, respectively. $\alpha$ is a parameter included to account for other processes, such as wind and solar irradiation, following Ashton (1986).

Equation (2) is inaccurate when the snow/ice layer is thin, so Eq. (3) was used to calculate $z_{\mathrm{b}}$ when snow and white ice are absent:

$z_{\mathrm{b}}=\alpha \sqrt{\frac{2 k_{\mathrm{i}}}{\rho_{\mathrm{i}} \Delta \mathrm{H}_{\mathrm{fus}}} \int\left(0^{\circ} \mathrm{C}-T_{\mathrm{air}}\right) \mathrm{d} t}$,

where $T_{\text {air }}$ is integrated over time since freeze-up. This formula represents an analytical solution to the differential equation describing black ice growth (of which Eq. (2) is the discretized form) and was applied before the first date of observed snowfall.

The assumptions underlying Eqs. (2) and (3) are invalid for $T_{\text {air }}>0$, which was the case on 4 consecutive days in October 2010 after freeze-up, but we applied this model as an approximation. Previous studies of melting ice found the formation of channels within lake ice instead of decreasing thickness (e.g., Browman, 1974; Nye, 1989; Jakkila et al., 2009), so we assume zero ice growth around trapped bubbles during this period.

The snow's thermal conductivity was calculated from its density (Sturm et al., 1997), which was estimated from measurements of precipitation and snow depth (Sect. 2.2.8). We assumed that decreases in measured snow depth resulted only from compaction and not sublimation, which resulted in our underestimating the maximum black ice thickness by at most $9 \mathrm{~cm}$ (Liston and Sturm, 2002).

Occasionally, the weight of snow depresses the ice surface beneath the water level, causing lake water to flood the ice surface and form white ice (i.e., a flooding event). The white ice thickness was increased during such events according to the thickness of water required to balance the weight of the snow/ice layer:

$\Delta z_{\mathrm{w}}=\frac{\rho_{\mathrm{i}}}{\rho_{\mathrm{w}} \rho_{\mathrm{s}}}\left(z_{\mathrm{s}} \rho_{\mathrm{s}}-z_{\mathrm{i}} \rho_{\mathrm{i}}-z_{\mathrm{i}} \rho_{\mathrm{w}}\right)$

where $\rho_{\mathrm{s}}$ and $\rho_{\mathrm{w}}$ are the densities of snow and water, respectively. The volume, $V_{\text {flood }}$, and $\mathrm{CH}_{4}$ concentration of water involved in each flooding event determined the amount of $\mathrm{CH}_{4}$ released to the atmosphere:

$V_{\text {flood }}=\Delta z_{\mathrm{w}} A\left(1-\frac{\rho_{\mathrm{s}}}{\rho_{\mathrm{i}}}\right)$,

where $A$ is the lake area $\left(10030 \mathrm{~m}^{2}\right)$.

The daily change in lake snow depth was calculated as the change in the measured snow depth on land minus $\Delta z_{\mathrm{w}}$. An $\alpha$ value of 0.95 yielded the best fit to the measured total ice thickness during the winter of 2011-2012 (Fig. 5d). A second model was constructed for 2010-2011 in which the snow density was set to $450 \mathrm{~kg} \mathrm{~m}^{-3}$ (Bohren and Beschta, 1979; Fancy and White, 1985) on days when the measurement site was visited so that modeled thicknesses could be compared to measured ice thicknesses at the disturbed (artificially compacted) site. An $\alpha$ value of 0.94 yielded the best fit to these data (Fig. 6). Due to the similarity of $\alpha$ values during both winter periods and the greater number of measurements in 2011-2012, an $\alpha$ value of 0.95 was used to calculate undisturbed ice thicknesses in the model.

\subsubsection{Methane dissolution from bubbles}

The model uses Eq. (1) with $60 \mathrm{~s}$ time steps to simulate $\mathrm{CH}_{4}$ diffusion from trapped bubbles into the upper layer of the water column. We calculated that typical ebullition bubbles in Goldstream Lake $(6.3 \pm 0.2 \mathrm{~mm}$ bubble diameter measured at the lake surface, mean \pm standard deviation, $n=433)$ lose $<1 \%$ of their $\mathrm{CH}_{4}$ during their ascent through the $\leq 2.9 \mathrm{~m}$ water column (Woolf and Thorpe, 1991; Holocher et al., 2003), which is significantly less than the difference in $\mathrm{CH}_{4}$ contents of fresh and encapsulated bubbles (Sect. 2.2.6). Methane dissolution from rising bubbles was 

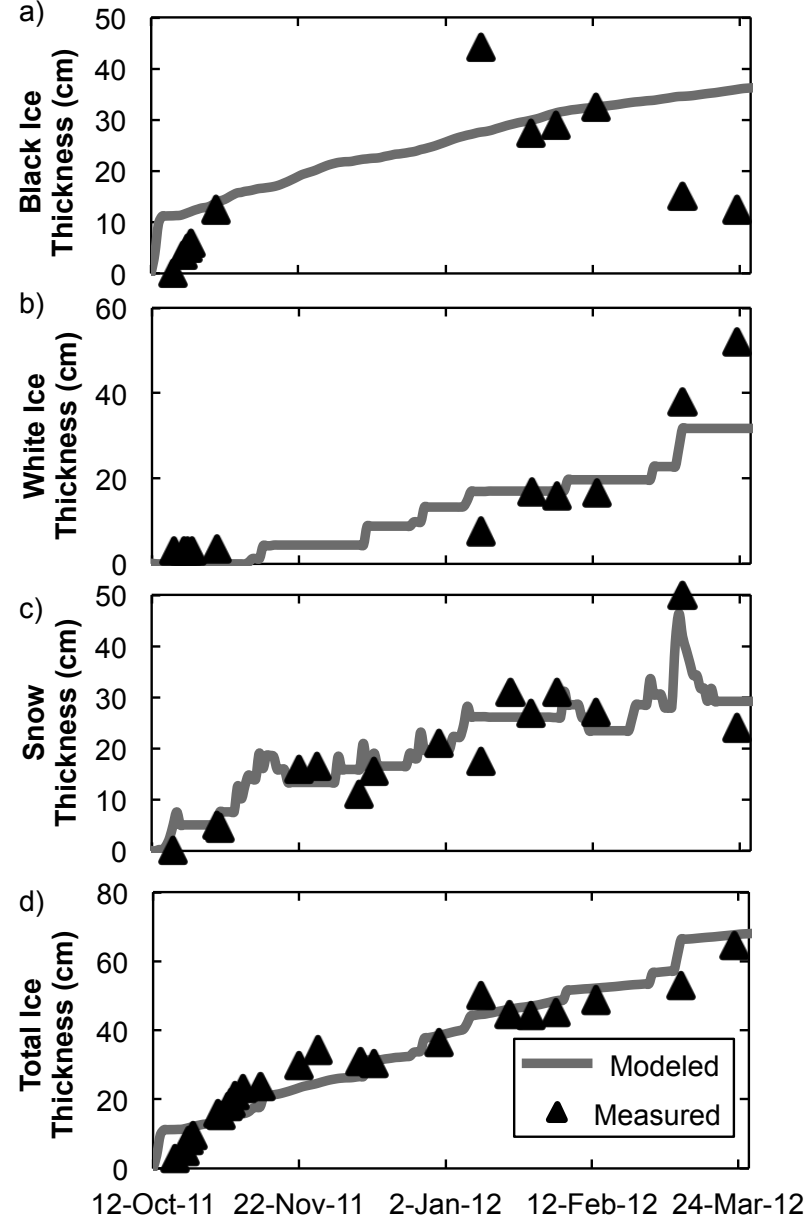

Figure 5. Modeled and measured thicknesses of (a) black ice, (b) white ice, (c) lake surface snow, and (d) the ice layer (white and black ice) during the winter of 2011-2012. A value of $\alpha=0.95$ was used in the ice growth model (Sect. 2.3.2) for this period.

therefore neglected, an approximation similarly employed by Stepanenko et al. (2011).

The shapes of trapped bubbles at each seep site determine the area over which $\mathrm{CH}_{4}$ dissolves out. All ebullition bubbles at each site are modeled as a single gas pocket. We tested this approximation by modeling multiple pockets at each site (20 at A seep sites and 10 at B seep sites, representative of the number of bubbles found at typical sites in these seep classes), and found that this had a negligible $(<0.5 \%)$ effect on the total amount of $\mathrm{CH}_{4}$ that dissolved into the water column during the ice-cover periods.

At each seep site, the model tracks the growth of a cavity within the ice layer, caused by the localized inhibition of ice growth. If the total volume of gas exceeds the cavity's volume, the gas beneath the ice-water interface is modeled as a cylinder. At A, B, and C seep sites, the height of this cylinder is $5.7 \mathrm{~mm}$, as informed by measurements of air bubbles of known volume that we artificially introduced beneath the ice in Goldstream Lake. The cylinder's radius determines

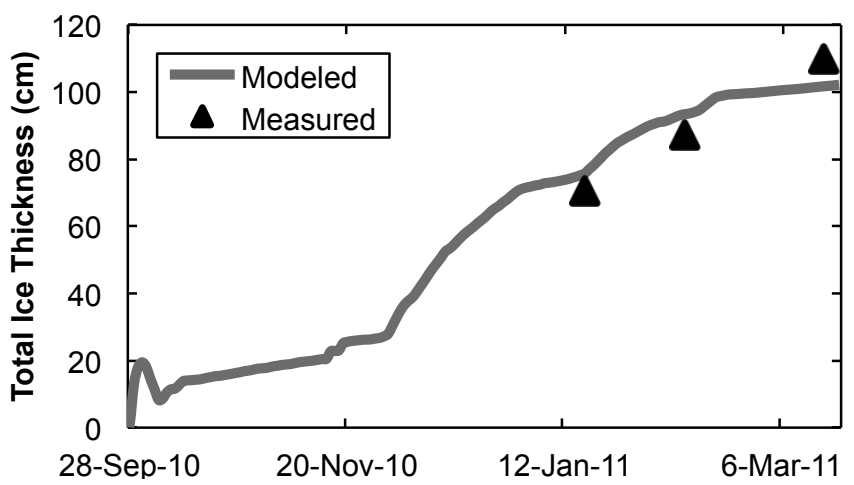

Figure 6. Modeled and measured total thicknesses of the ice layer (white and black ice) during the winter of 2010-2011. Measurements were obtained in areas where snow was occasionally compacted by foot traffic, an effect accounted for in the modeled thickness. A value of $\alpha=0.94$ was used in the ice growth model for this period.

that of the cavity as the ice grows downward. The cylinder's volume and radius decrease as $\mathrm{CH}_{4}$ diffuses out and the ice grows downward, causing cavities to taper at the bottom. At the beginning of each day, a bubble is added to the site, with a $\mathrm{CH}_{4}$ composition and volume determined from measurements (Sect. 2.2.6). When no gas remains beneath the icewater interface, the site's bubbles are considered encapsulated. Since the rate of gas diffusion in ice is typically negligible compared to that in water (Hemmingsen, 1958), we assumed that the $\mathrm{CH}_{4}$ content of bubbles remained constant after encapsulation. Figure 7a summarizes this component of the model.

At Hotspot seep sites, warmer water brought to the surface by frequent ebullition events inhibits ice growth and affects the shapes of cavities. Following Zimov et al. (2001), Hotspot sites were opened to the atmosphere when the daily maximum air temperature exceeded $-15^{\circ} \mathrm{C}$. The shape of Hotspot cavities was determined by averaging measurements of three cavities in Goldstream L. The bottom radius of the cavity determined the radius of the cylinder beneath the icewater interface. Bubbles were added to Hotspot seep sites every $8 \mathrm{~min}$, according to our field observations. We found that changing this interval to 1 and $20 \mathrm{~min}$, both within the range of variability of our observations, affected the total amount of $\mathrm{CH}_{4}$ that dissolves annually from Hotspot bubbles by no more than $0.05 \%$. Hotspot cavities never closed at the bottom, and when the total volume of gas was less than the cavity volume, the cavity's interior shape determined the area of gas exposed to lake water (Fig. 7b).

\subsubsection{Release of ice-trapped bubbles}

The spring ice-melt period begins on the first day of abovefreezing air temperatures and ends on the observed ice-off date. During this period, vertical melt channels spanning the 
ice layer form between black ice crystals with horizontal $c$ axes and tend to grow larger as melt progresses, facilitating the transport of water and trapped gas (Browman, 1974). The absorption of solar radiation within the ice layer accelerates this process, particularly after the high-albedo snow cover has melted completely (Williams, 1969; Ashton, 1986; Jakkila et al., 2009), as does the presence of ice-trapped bubbles (our observation when harvesting ice blocks; A. Bondurant, personal communication, 2014). Time-lapse photos indicate significant spatial and temporal variability in the surface albedo of Goldstream Lake during the spring melt period, suggesting that ice permeability was also highly variable.

Ebullition seeps can open prior to ice-off when water pressure breaks the ice separating encapsulated bubbles ( $\mathrm{Zi}$ mov et al., 2001). In agreement with the findings of Sasaki et al. (2009), we observed the opening of ebullition seeps throughout the thaw period, indicated by (1) open holes in ice at the locations of former ice-trapped bubbles, (2) rapid but short-lived (usually $<1 \mathrm{~min}$, but occasionally $>10 \mathrm{~min}$ ) streams of bubbles escaping from ice through puddles of water on the ice surface, and (3) the lack of gas escape from gas pockets in ice when punctured with an ice spear. We observed that seep sites with higher ebullition flux opened earlier, presumably due to thinner ice between encapsulated bubbles. On each day, the number of open seep sites in each class was increased according to a release rate function informed by these field observations (Fig. B3). Bubble dissolution at closed sites during this period was simulated assuming a zero ice growth rate.

\subsubsection{Water column dissolved gases}

During the winter ice-cover periods of the model, we assume that dissolved $\mathrm{CH}_{4}$ is excluded from water as it freezes. This is consistent with observations of $\mathrm{CH}_{4}$ concentrations in boreal lake ice 10 to 100 times lower than in the underlying water column (Phelps et al., 1998). In some cases, the exclusion of dissolved $\mathrm{CH}_{4}$ from downward-growing ice leads to the formation of millimeter-scale-diameter tubular bubbles within ice (Adams et al., 2013; Boereboom et al., 2012). Such bubbles were not obvious to us in ice blocks from Goldstream Lake, so the model did not include this process. We assume no gas exchange between the water column and the atmosphere during the winter ice-cover periods except for the release of dissolved $\mathrm{CH}_{4}$ from water on the ice surface during flooding events (Sect. 2.3.2).

The rate of $\mathrm{CH}_{4}$ consumption by methanotrophy, $r$, was calculated according to a double Monod equation (Van Bodegom et al., 2001):

$r=r_{\max }\left(\frac{\left[\mathrm{CH}_{4}\right]}{K_{\mathrm{S}, \mathrm{CH}_{4}}+\left[\mathrm{CH}_{4}\right]}\right)\left(\frac{\left[\mathrm{O}_{2}\right]}{K_{\mathrm{S}, \mathrm{O}_{2}}+\left[\mathrm{O}_{2}\right]}\right)$,

where $\left[\mathrm{CH}_{4}\right]$ and $\left[\mathrm{O}_{2}\right]$ denote the concentrations of dissolved $\mathrm{CH}_{4}$ and $\mathrm{O}_{2}$, respectively; $r_{\max }$ is the potential maximum a)

White Ice
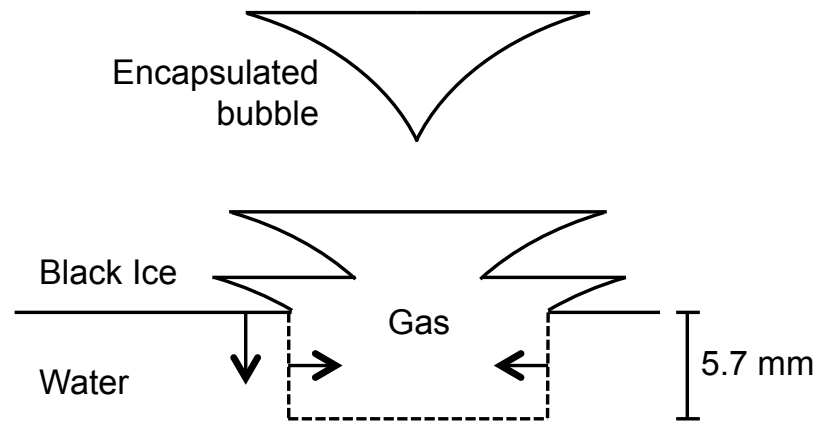

b)

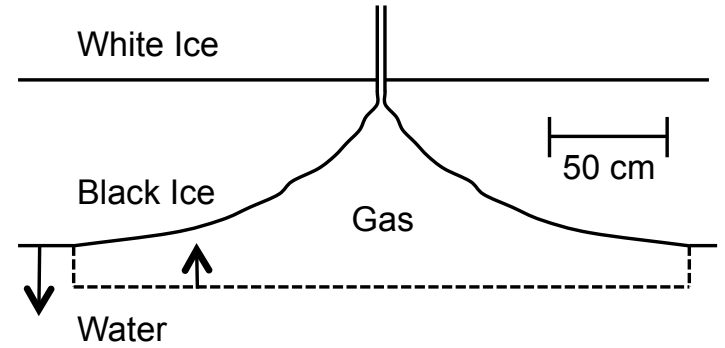

Figure 7. (a) A cross section of the model's representation of trapped gas at A, B, and C seep sites. The dashed line indicates the area over which $\mathrm{CH}_{4}$ dissolves into the water column. Gas beneath the ice-water interface is modeled as a cylinder with constant height $(5.7 \mathrm{~mm})$. The volume and radius of this cylinder decrease (indicated by arrows) as the ice grows downward and $\mathrm{CH}_{4}$ diffuses out, giving rise to the tapering shape of encapsulated bubbles. (b) Schematic of a closed Hotspot seep site. The cavity's shape is determined by field measurements, and its bottom radius determines that of the cylinder of gas beneath the ice-water interface. The height of this cylinder decreases as $\mathrm{CH}_{4}$ diffuses out and the ice grows downward (indicated by arrows). Note the different scales in (a) and (b).

methanotrophic rate; and $K_{\mathrm{S}, \mathrm{CH}_{4}}$ and $K_{\mathrm{S}, \mathrm{O}_{2}}$ are the affinity constants for $\mathrm{CH}_{4}$ and $\mathrm{O}_{2}$, respectively. We used a $K_{\mathrm{S}, \mathrm{CH}_{4}}$ of $0.110 \mathrm{mg} \mathrm{L}^{-1}$ (Liikanen et al., 2002; Lofton et al., 2014), a $K_{\mathrm{S}, \mathrm{O}_{2}}$ of $0.672 \mathrm{mg} \mathrm{L}^{-1}$ (Lidstrom and Somers, 1984), and an estimated $r_{\max }$ of $0.48 \mathrm{mg} \mathrm{L}^{-1} \mathrm{~d}^{-1}$ based on measurements in Goldstream Lake by Martinez-Cruz et al. (2014). In both years of the model, dissolved $\mathrm{O}_{2}$ was depleted within 60 days of freeze-up, after which the methanotrophic rate was essentially 0 until the spring ice-melt period (Fig. 8b). Measured $\mathrm{O}_{2}$ concentrations followed a similar trend as modeled $\mathrm{O}_{2}$ concentrations during the ice-cover periods. We assumed uniform water column $\mathrm{CH}_{4}$ and $\mathrm{O}_{2}$ concentrations in the winter before the spring ice-melt periods, as we found that imposing the vertical gradients observed in our field measurements would have minor effects on the magnitude of $\mathrm{CH}_{4}$ dissolution from bubbles and the magnitude of $\mathrm{CH}_{4}$ emissions from flooding events. Our field measurements suggest that assuming uniform concentrations resulted in our 


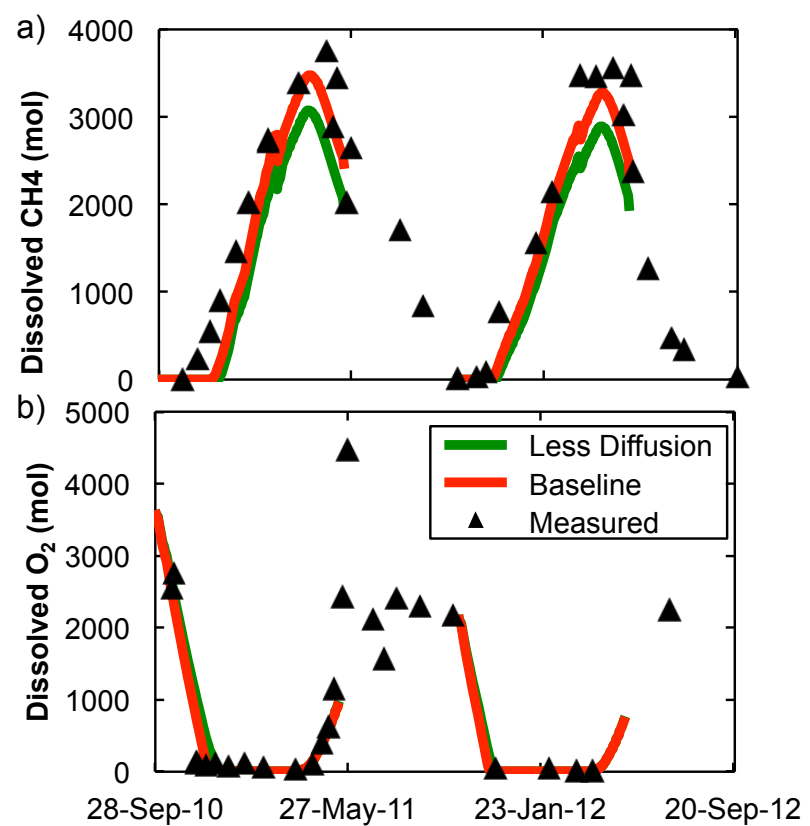

Figure 8. The measured amounts of (a) $\mathrm{CH}_{4}$ and (b) $\mathrm{O}_{2}$ dissolved in the water column of Goldstream Lake during the study period, and those calculated in the baseline and "less diffusion" versions of the model (Sect. A1).

underestimating the magnitude of $\mathrm{CH}_{4}$ emissions from flooding events during the study period by ca. $5 \%$.

The rate of water-atmosphere gas exchange during ice melt depends on the extent of ice permeability and the advection of water through ice, both of which are poorly constrained. The methanotrophic rate depends on the availability of dissolved $\mathrm{O}_{2}$, which is spatially irregular. Furthermore, methanotrophy sometimes does not resume until after an "induction period" following the reintroduction of $\mathrm{O}_{2}$. Induction periods of 0 to $20 \mathrm{~d}$ have been observed in soils and in Arctic lakes (Bender and Conrad, 1995; Dunfield et al., 1999; Martinez-Cruz et al., 2014).

To account for these uncertainties, the model includes two parameters adjusted to fit modeled amounts of dissolved $\mathrm{CH}_{4}$ and $\mathrm{O}_{2}$ during the spring ice-melt periods to measurements (Fig. 8). The amount in moles of $\mathrm{CH}_{4}, \mathrm{R}$, released to the atmosphere on each day by diffusion from the upper $1.25 \mathrm{~m}$ of the water column was calculated as follows:

$R=s p_{1} D_{\mathrm{CH}_{4}}\left(\left[\mathrm{CH}_{4}\right]-\left[\mathrm{CH}_{4}\right]_{\mathrm{eq}}\right)$,

where $s$ is the total number of seep sites open to the atmosphere, $p_{1}$ is an adjustable parameter (with units $\mathrm{ms} \mathrm{site}^{-1}$ ), and $\left[\mathrm{CH}_{4}\right]$ represents the average modeled $\mathrm{CH}_{4}$ concentration in the upper layer. The amount of $\mathrm{O}_{2}$ diffusing into the upper layer from the atmosphere was calculated with the same $p_{1}$ and $s$ parameters. As suggested by field measurements, $\mathrm{O}_{2}$ did not diffuse into the lower layer (deeper than $1.25 \mathrm{~m}$ ). The rate of $\mathrm{CH}_{4}$ consumption was calculated ac-
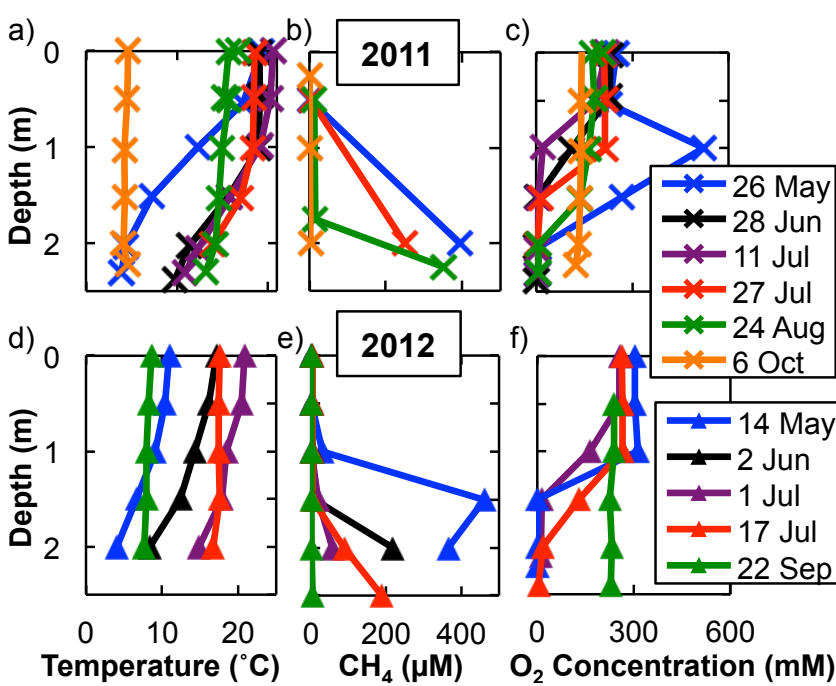

Figure 9. Measured depth profiles of $(\mathbf{a}, \mathbf{d})$ temperature, $(\mathbf{b}, \mathbf{e})$ dissolved $\mathrm{CH}_{4}$ concentration, and $(\mathbf{c}, \mathbf{f})$ dissolved $\mathrm{O}_{2}$ concentration in the water column of Goldstream Lake during the summers of 2011 and 2012. 2011 profiles indicate that fall overturn had occurred by 6 October 2011.

cording to Eq. (6) and scaled by the second adjustable parameter.

We did not observe a decrease in dissolved $\mathrm{CH}_{4}$ or an increase in $\mathrm{O}_{2}$ in the hypolimnion of Goldstream Lake immediately following ice-off, suggesting that the water column remained stratified as surface temperatures increased. Others have similarly observed water column stability in Arctic lakes during and after spring melt, which they attributed to intense solar radiation and the inflow of meltwater from surrounding areas (Bergmann and Welch, 1985; Burn, 2002; Bastviken et al., 2004). Measured $\mathrm{CH}_{4}$ concentrations in the upper $1 \mathrm{~m}$ of the water column increased significantly during a period of ca. 12 days in early May 2012 spanning the date of observed ice-off, suggesting significant upper-layer mixing during that time. Measured temperature profiles indicate a similar phenomenon in May 2011. As an approximation, all $\mathrm{CH}_{4}$ in the upper layer of the water column was released to the atmosphere over a period of 5 days following ice-off.

The rate of dissolved $\mathrm{CH}_{4}$ diffusion to the atmosphere during the ice-free period was calculated by multiplying the difference between the measured surface $\mathrm{CH}_{4}$ concentration and the equilibrium $\mathrm{CH}_{4}$ concentration on each day by a "gas-transfer coefficient", $k$. We used a $k$ determined empirically by Cole and Caraco (1998), representing an average $k$ for the open-water period at Mirror Lake, a low-wind temperate lake. We converted it appropriately using a Schmidt number for $\mathrm{CH}_{4}$ at $10^{\circ} \mathrm{C}$ of 1052 (Wania et al., 2010), which gave a $k$ for $\mathrm{CH}_{4}$ of $1.82 \mathrm{~cm} \mathrm{~h}^{-1}$. As we did not measure wind velocities at Goldstream Lake during the study period, we were unable to apply the wind-dependent parameterization of $k$ presented by Cole and Caraco (1998). However, we 
believe this did not significantly affect our results for two reasons: (1) Goldstream Lake is surrounded by trees, suggesting that wind speeds there are similar to those at the low-wind lake measured by Cole and Caraco, and (2) Cole and Caraco noted that $k$ is relatively independent of wind speed at low wind speeds, suggesting that any difference in average wind speed between Mirror Lake and Goldstream Lake would not have appreciably affected the value of $k$. The value of $k$ we used differed by $2 \%$ from that applied by Kling et al. (1992) to lakes on the northern coastal plain of Alaska, which are presumably windier than Goldstream Lake. Kling et al. noted that they likely underestimated the rate of gas diffusion from these lakes, suggesting that applying this value of $k$ for Goldstream Lake is justified.

Measured concentrations from 2012 were used during the summer of 2011 because surface $\mathrm{CH}_{4}$ concentrations were not measured in 2011. The similarities between $\mathrm{CH}_{4}$ concentration-depth profiles obtained during both openwater periods (Fig. 9) suggest that surface $\mathrm{CH}_{4}$ concentrations were also similar. The mean daily rate of $\mathrm{CH}_{4}$ diffusion to the atmosphere during both open-water periods $\left(1.2 \mathrm{mmol} \mathrm{m}^{-2} \mathrm{~d}^{-1}\right)$ was within the range of observations for other boreal lakes (Phelps et al., 1998; Huttunen et al., 2003; Walter et al., 2006). We assumed that $\mathrm{CH}_{4}$ not emitted to the atmosphere during this period was consumed by methanotrophy.

During the summer of 2011, our measurements of water temperature, dissolved $\mathrm{CH}_{4}$, and dissolved $\mathrm{O}_{2}$ indicated a gradual deepening of the epilimnion in Goldstream Lake (Fig. 9). On 6 October 2011, we observed uniform depth profiles for all of these variables, low $(<3 \mu \mathrm{M})$ dissolved $\mathrm{CH}_{4}$ concentrations, and high $(156 \mathrm{mM}) \mathrm{O}_{2}$ concentrations, suggesting that fall overturn had occurred by then. Similar trends in temperature and dissolved $\mathrm{O}_{2}$ concentrations were observed during the open-water period in 2012. Surface $\mathrm{O}_{2}$ concentrations remained high throughout this period in 2011 , while surface $\mathrm{CH}_{4}$ concentrations remained low, suggesting that methanotrophy in the upper layer of the water column prevented the significant release of $\mathrm{CH}_{4}$ dissolved in the hypolimnion to the atmosphere before and during overturn. Kankaala et al. (2007) similarly estimated that the majority (83-88\%) of dissolved $\mathrm{CH}_{4}$ in the hypolimnion of a lake in Finland was consumed by methanotrophy during fall overturn. The amount of dissolved $\mathrm{CH}_{4}$ before freeze-up was set to 0 , as suggested by our measurements, and the amount of dissolved $\mathrm{O}_{2}$ was determined from measurements.

\subsection{Statistical analysis}

Heteroscedastic $t$ tests were performed using Excel (Microsoft, Redmond, Washington, USA).

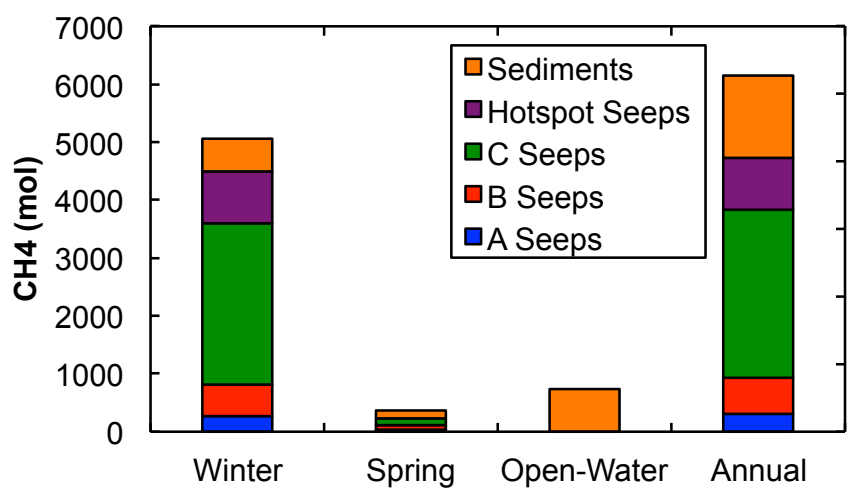

Figure 10. Seasonal and annual quantities of $\mathrm{CH}_{4}$ dissolving into the water column from ebullition seeps and sediments in the baseline version of the model. Annually, $77 \%$ of dissolved $\mathrm{CH}_{4}$ in Goldstream Lake originates from ebullition bubbles trapped beneath winter ice, and $23 \%$ from $\mathrm{CH}_{4}$ diffusion from bottom sediments.

\section{Results and discussion}

\subsection{Evidence of bubble dissolution}

Our model of $\mathrm{CH}_{4}$ dissolution from submerged, gas-filled mesocosm chambers (Sect. 2.2.7) suggests that a significant amount of $\mathrm{CH}_{4}$ dissolves out of bubbles on the timescale of bubble encapsulation (days to months). This model agrees with measured volumes and $\mathrm{CH}_{4}$ compositions of gas in chambers, except at 145 and $165 \mathrm{~h}$ in the fall trial (Fig. 4). We observed defects in the ebullition deflectors on those chambers, and our weather observations indicate a decrease in barometric pressure prior to $145 \mathrm{~h}$, which is known to induce ebullition events (Mattson and Likens, 1990). We therefore attribute these discrepancies to the addition of natural ebullition bubbles.

Measurements of $\mathrm{CH}_{4}$ concentrations in bubbles trapped within the ice layer also indicate significant dissolution. At C seep sites, fresh bubbles collected immediately after their ascent through the water column (Sect. 2.2.6) had significantly greater $\mathrm{CH}_{4}$ concentrations than encapsulated bubbles $(85 \%$ vs. $72 \%, t$ test, $p<0.05)$. However, we did not find significant differences between the concentrations of encapsulated vs. fresh A- and B-type bubbles due to a paucity of field measurements (zero and two encapsulated A- and B-type bubbles were sampled, respectively).

\subsection{Baseline results}

Both the model as described in Sect. 2.3 (the baseline version) and our measurements indicate that dissolved $\mathrm{CH}_{4}$ accumulates in Goldstream Lake throughout the ice-cover periods, reaching maxima approximately 1 month prior to iceoff (Fig. 8a). The measured maximum concentrations (400 and $337 \mu \mathrm{M}$ in 2011 and 2012 , respectively) are within the range of measurements for other lakes in Alaska (Phelps et 


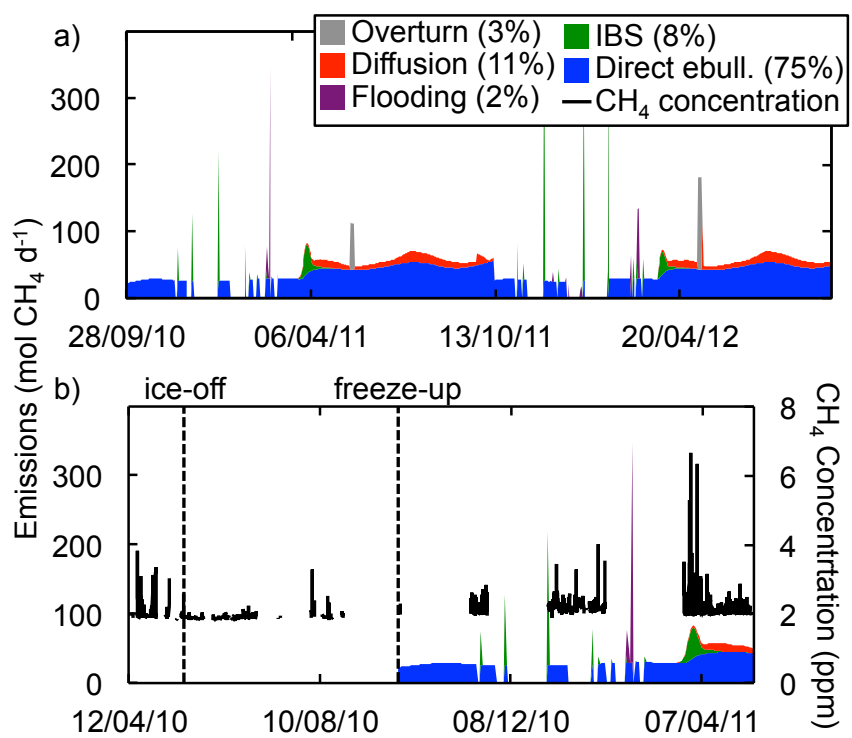

Figure 11. (a) Modeled daily $\mathrm{CH}_{4}$ emissions to the atmosphere by each of the five mechanisms discussed in Sect. 3.2 in the baseline version of the model. Percentages in the legend denote the fraction of total annual emissions from each emissions mode. (b) Measured atmospheric $\mathrm{CH}_{4}$ concentrations over Goldstream Lake shown with modeled emissions during a portion of the study period. In 2011 iceoff occurred on 15 May, after the period shown.

al., 1998). Figure 10 shows the relative contributions of all sources of dissolved $\mathrm{CH}_{4}$ in the model.

We calculated annual atmospheric $\mathrm{CH}_{4}$ emissions by five distinct mechanisms: (1) the direct release of bubbles from open ebullition seep sites ("direct ebullition"), (2) the release of free-phase gas trapped by the ice layer ("IBS"), (3) emission during winter flooding events ("flooding", Sect. 2.3.2), (4) diffusion of dissolved $\mathrm{CH}_{4}$ from the water column ("diffusion"), and (5) emission during partial lake overturn events ("overturn"). Bastviken et al. (2004) referred to the fifth mechanism as "storage flux", but we termed it "overturn" to distinguish it from the release of "stored" $\mathrm{CH}_{4}$ by diffusion through open ebullition seep sites during the spring melt period prior to lake overturn. Figure 11 shows emissions from the entire surface of Goldstream Lake by each of these modes.

Periods of zero emissions correspond to periods of atmospheric temperatures below $-15^{\circ} \mathrm{C}$, when Hotspot seeps in the model were closed. When Hotspot seeps reopened, IBS emissions peaked due to the sudden release of gas within cavities. In reality, other factors, including ebullition rates and ice morphology, govern the opening and closing of Hotspot seep sites, so Hotspot IBS emissions may actually be distributed more evenly throughout the ice-cover period. This is a potential reason why peaks in the measured atmospheric $\mathrm{CH}_{4}$ concentration occurred more frequently than peaks in Hotspot IBS emissions during the winter of 20102011 (Fig. 11b). For this reason, and because there are no field observations to validate our representation of the geometry of gas beneath the ice-water interface at Hotspot seep sites, our estimates of the magnitude and timing of Hotspot IBS emissions are likely uncertain. The average daily rate of atmospheric $\mathrm{CH}_{4}$ emissions was highest during the spring ice-melt periods $\left(70 \mathrm{molCH}_{4} \mathrm{~d}^{-1}\right)$ due to emission of dissolved and trapped free-phase $\mathrm{CH}_{4}$, and lowest during the winter ice-cover periods $\left(24 \mathrm{~mol} \mathrm{CH}_{4} \mathrm{~d}^{-1}\right)$ due to the impediment of ebullition bubbles by lake ice. The atmospheric $\mathrm{CH}_{4}$ concentration measured above Goldstream Lake peaked significantly in early April 2011, when modeled IBS emissions also peaked (Fig. 11b). This supports our representation of bubble release prior to ice-off in the model (Sect. 2.3.4). A period of elevated atmospheric concentrations prior to iceoff was also observed in 2010. On average, 75 and $8 \%$ of annual atmospheric $\mathrm{CH}_{4}$ emissions occurred via direct ebullition and IBS, respectively, during the 2-year study period (Fig. 11). IBS emissions constituted 6 and $9 \%$ of annual emissions from Goldstream Lake in each year (2010-2011 and 2011-2012, respectively).

The majority (67\%) of $\mathrm{CH}_{4}$ released annually from the bottom sediments of Goldstream Lake by ebullition seeps in the model was emitted directly to the atmosphere, unimpeded by lake ice (Fig. 12a). This proportion is determined primarily by the ebullition flux from Hotspot seeps, which remain open to the atmosphere throughout much of the icecover period. Ebullition from Hotspot seeps constitutes $48 \%$ of the total annual seep ebullition flux from sediments in Goldstream Lake. Efforts to improve estimates of $\mathrm{CH}_{4}$ emissions from Goldstream Lake should therefore focus first on direct ebullition emissions, particularly those from Hotspots. Our estimate of direct ebullition is conservative because it does not include ebullition from non-seep "background" locations. Walter et al. (2006) found that background ebullition comprises $25 \%$ of total annual $\mathrm{CH}_{4}$ emissions from two Siberian thermokarst lakes and was highest in the summer, when microbes in warm surface sediments produce $\mathrm{CH}_{4}$ that is released from non-seep locations. Our preliminary data from bubble traps over non-seep locations, as identified by bubble-free ice in the early winter, suggest that background ebullition also occurs in Goldstream Lake.

The model indicates that seasonal ice cover effectively impedes the release of ebullition $\mathrm{CH}_{4}$ to the atmosphere. During the ice-cover period, $44 \%$ of $\mathrm{CH}_{4}$ bubbling from sediments dissolved into the water column when bubbles were trapped by ice. Conversely, $45 \%$ was released by direct ebullition from Hotspots and A, B, and C seep sites open during spring melt, and $11 \%$ was trapped as free-phase gas by ice. On an annual basis, $7 \%$ of the total seep ebullition flux was trapped as IBS and later released to the atmosphere when ice melted. The majority of IBS emissions was associated with Hotspots reopening in the winter (Fig. 12a).

Of the $\mathrm{CH}_{4}$ in seep ebullition bubbles impeded by lake ice, $80 \%$ ultimately dissolved into the water column, and $56 \%$ of this dissolved $\mathrm{CH}_{4}$ was consumed by methanotrophy 
Table 1. Names of the versions of the model discussed as sensitivity analyses in Sects. 3.4 and 3.5 and Appendix A, and descriptions of how they differ from the baseline version, described in Sect. 2.3. At right, the fraction of $\mathrm{CH}_{4}$ in each version released annually from the sediments of Goldstream Lake, either by diffusion or ebullition, that is emitted to the atmosphere without being consumed by methanotrophy.

\begin{tabular}{|c|c|c|}
\hline Version name & Difference from baseline & $\begin{array}{l}\text { Fraction of } \mathrm{CH}_{4} \\
\text { emitted to the } \\
\text { atmosphere }\end{array}$ \\
\hline Baseline & - & $82 \%$ \\
\hline Less diffusion & $\begin{array}{l}\text { Diffusion rate from lake bottom sediments is } 5 \text { times less } \\
\text { than in the baseline version. }\end{array}$ & $86 \%$ \\
\hline More/less black ice & Snow density is held constant at $300 \mathrm{~kg} \mathrm{~m}^{-3} / 100 \mathrm{~kg} \mathrm{~m}^{-3}$. & $81 \% / 84 \%$ \\
\hline Greater/lesser $\delta_{\text {eff }}$ & $\begin{array}{l}\delta_{\text {eff }} \text { set to } 0.15 \mathrm{~mm} / 0.35 \mathrm{~mm} \text { in the bubble dissolution com- } \\
\text { ponent. }\end{array}$ & $83 \% / 81 \%$ \\
\hline Episodic ebullition & $\begin{array}{l}\text { Measured ebullition rates from individual seeps are ap- } \\
\text { plied to seeps in the model instead of time-smoothed rates } \\
\text { (Sect. 2.2.6). }\end{array}$ & $83 \%$ \\
\hline Early/late release & $\begin{array}{l}\text { All bubbles trapped at A, B, and C seep sites are released } \\
\text { on the first/last day of the spring ice-melt period in the } \\
\text { model instead of throughout. }\end{array}$ & $81 \% / 85 \%$ \\
\hline Warmer climate & Air temperatures are increased uniformly by $5^{\circ} \mathrm{C}$. & $85 \%$ \\
\hline
\end{tabular}

(Fig. 12b). In the model, the extent of winter methanotrophy is determined entirely by the amount of $\mathrm{O}_{2}$ dissolved in the water column at the time of freeze-up. Eighty-two percent of the total amount of $\mathrm{CH}_{4}$ emitted annually from the sediments of Goldstream Lake by seep ebullition and diffusion reached the atmosphere without being oxidized (Table 1). Because the amount of $\mathrm{CH}_{4}$ that dissolves out of bubbles during the ice-cover period is much greater than the amount that diffuses out of sediments (Fig. 10), ice cover facilitates substantially greater $\mathrm{CH}_{4}$ dissolution into the water column and therefore increased methanotrophy.

The shapes of ebullition bubbles in harvested ice blocks (Sect. 2.2.6) varied greatly, depending on the seep type, ice growth rates, and the degree of bubble coalescence. Individual bubbles often tapered at the bottom, but vertically joined bubbles sometimes had tapering tops (Fig. 13c). For comparison with observations, the bubble dissolution component of the model was executed in isolation to simulate $\mathrm{CH}_{4}$ dissolution from a single trapped bubble, assuming a constant ice growth rate and zero dissolved $\mathrm{CH}_{4}$ concentration. We fit the shapes of modeled bubbles to measurements by adjusting the ice growth rate and initial volume. Results agreed reasonably with measurements of bubbles that tapered at the bottom, and fits were better for bubbles with more concave sides (Fig. 13a). Bubble radii calculated assuming a constant dissolved $\mathrm{CH}_{4}$ concentration of $387 \mu \mathrm{M}$, the maximum concentration observed during the study period, differed from those in our original results by no more than $1 \mathrm{~mm}$, suggesting that bubble shapes are more strongly influenced by the ice growth rate than the rate of $\mathrm{CH}_{4}$ dissolution. Discrepancies between calculated and measured shapes likely arose from fluctuations in the ice growth rate and the error associ- ated with modeling gas beneath the ice-water interface as a cylinder with constant height.

In the model, the decrease in bubble volume due to $\mathrm{CH}_{4}$ dissolution gives rise to the shape of bubbles that taper at the bottom, so no bubbles had flat bottoms or tapering tops. We attribute observations in lake ice blocks of the occasional formation of bubbles with this opposite orientation to the insulating effect of gas frozen within the ice layer (Engram et al., 2013), which causes ice around trapped bubbles to grow faster than ice directly beneath, giving rise to dome-shaped or conical cavities at ebullition seep sites. This effect may compete with the effect of volume loss to determine bubble shapes, therefore causing a distribution of both orientations. Further investigation is needed to determine the effect of localized ice growth inhibition on bubble shapes and $\mathrm{CH}_{4}$ dissolution.

Modeled $\mathrm{CH}_{4}$ concentrations of encapsulated bubbles did not differ significantly from measurements for bubbles at B and $C$ seep sites ( $t$ tests, $p>0.05$ ); however, only two encapsulated B-type bubbles and four C-type bubbles were sampled from Goldstream Lake. To increase the sample size, we also compared modeled concentrations to measurements of 30 encapsulated bubbles from four other thermokarst lakes in interior Alaska, the northern Seward Peninsula in Alaska, and northern Siberia (Walter et al., 2008; Sepulveda-Jauregui et al., 2014b). It was often impossible to classify ebullition sites beneath white ice during the spring ice-melt period as $\mathrm{A}, \mathrm{B}$, or $\mathrm{C}$, so measurements from all ebullition classes were pooled and adjusted to account for observed differences in fresh bubble $\mathrm{CH}_{4}$ concentrations among lakes (SepulvedaJauregui et al., 2014b). The mean adjusted concentration in encapsulated bubbles from other lakes $(58 \%)$ did not differ significantly from those measured in Goldstream Lake 


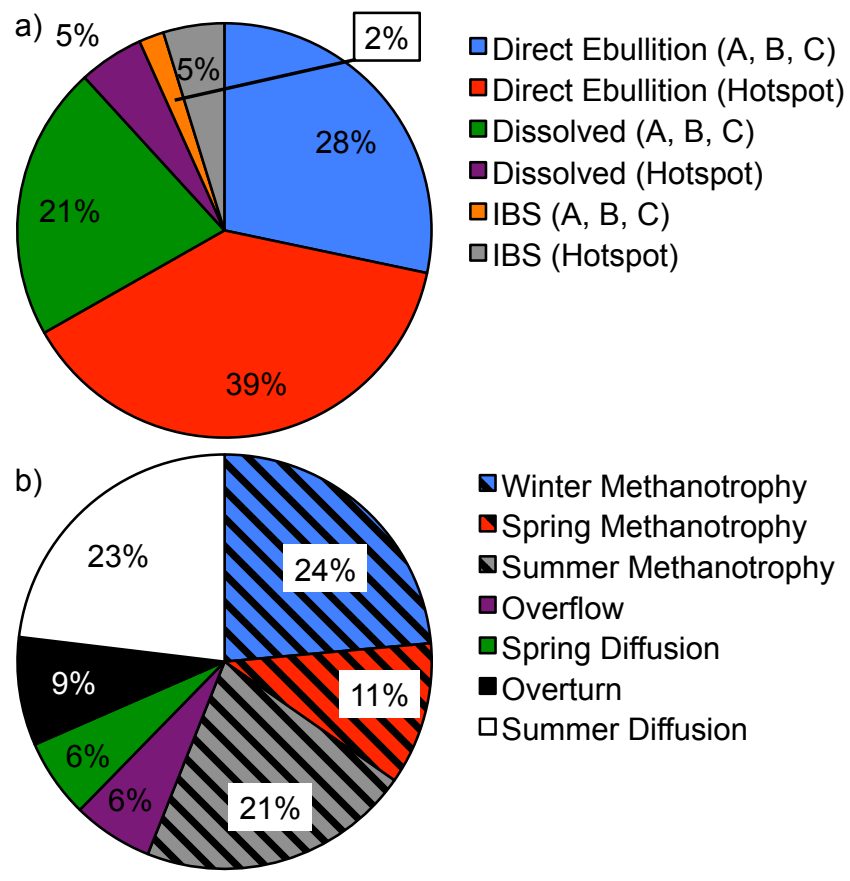

Figure 12. The fates of seep ebullition bubbles (a) and dissolved $\mathrm{CH}_{4}$ (b) during the 2-year study period, as calculated in the baseline version of the model. The names of the various modes of $\mathrm{CH}_{4}$ emission are discussed in Sect. 3.2.

(68\%; $t$ test, $p>0.05$ ), but the mean adjusted concentration for all five lakes $(60 \%)$ was significantly lower than modeled concentrations (69\%; $t$ test, $p<0.05$ ).

As a sensitivity analysis, we also constructed a version of the model, "episodic ebullition", in which individual seep fluxes, rather than smoothed fluxes, were applied during the ice-cover periods in the model. We found that encapsulated bubbles in the episodic ebullition version had a mean $\mathrm{CH}_{4}$ concentration (32\%) significantly less than both the mean measured concentration for all five lakes and the mean modeled concentration when smoothed fluxes were applied $(t$ tests, $p<0.001)$. The larger surface area, on average, of trapped gas pockets at non-Hotspot seep sites in the episodic ebullition version allowed more $\mathrm{CH}_{4}$ to dissolve out after individual ebullition events, despite the fact that gas pockets were encapsulated faster by ice (due to extended periods of no ebullition). Consequently, IBS emission from A, B, and $\mathrm{C}$ seep sites was $28 \%$ less than in the baseline version. The episodic ebullition version appeared to underestimate encapsulated bubble $\mathrm{CH}_{4}$ concentrations in comparison to observations from the five thermokarst lakes. One likely reason for this is that we assume the $5.7 \mathrm{~mm}$ bubble height measured on 20-40 mL gas pockets applies to all bubbles, but a $5000 \mathrm{~mL}$ ebullition event, which can occur in the episodic ebullition version, produces larger gas pockets with possibly different bubble heights. Secondly, we did not account for lateral migration of bubbles beneath ice in the model. a)

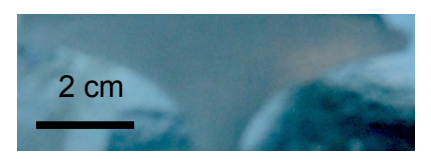

b)

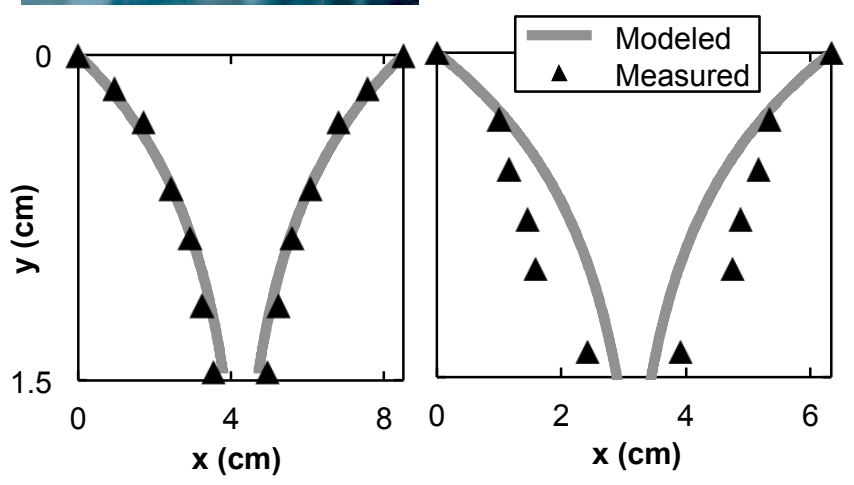

c)

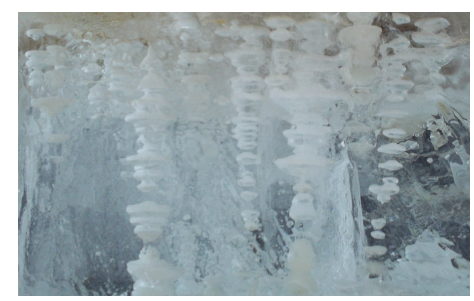

Figure 13. The shapes of bubbles encapsulated by lake ice above an A-type ebullition seep. Field measurements of bubbles (a) and (b) are compared to shapes calculated in the bubble dissolution component of the model (Sect. 2.3.3). Plots represent a side profile of bubbles, with the $y$ axis representing depth within the ice layer. Note the different scales on both axes. (c) Encapsulated bubbles oriented in both directions, either with flat bottoms and tapering tops or viceversa. Photos courtesy of Melanie Engram.

Results suggest that our slight overestimation of encapsulated bubble $\mathrm{CH}_{4}$ concentrations in the baseline version of the model arises from our applying smoothed ebullition fluxes. However, applying smoothed ebullition fluxes is justified for three reasons: (1) the magnitude of $\mathrm{CH}_{4}$ dissolution into the water column in the model was more sensitive to the magnitude of the $\mathrm{CH}_{4}$ ebullition flux during the ice-cover period than the timing of this release. This magnitude is more accurately represented by the larger sample size of measured seep fluxes that informed our calculation of smoothed fluxes. (2) The majority of $\mathrm{CH}_{4}$ in bubbles impeded by lake ice dissolves into the water column (Fig. 12), so major discrepancies in the mean $\mathrm{CH}_{4}$ concentration of encapsulated bubbles $(69 \%$ baseline vs. $32 \%$ episodic ebullition) result in only minor discrepancies in the magnitude of $\mathrm{CH}_{4}$ dissolution into the water column and therefore in the magnitude of annual $\mathrm{CH}_{4}$ emissions. In the episodic ebullition version, the total magnitude of $\mathrm{CH}_{4}$ dissolution from bubbles trapped at A, B, and C seep sites and the total annual $\mathrm{CH}_{4}$ emissions from Goldstream Lake were, respectively, 2.5 and $5.3 \%$ greater than those in the baseline version (Fig. A1). 
(3) It is more computationally efficient to execute the model using smoothed fluxes than with a large number of individual seeps.

\subsection{Additional "tinies" ebullition seeps}

Our field observations indicate a previously undefined class of ebullition seeps, "tinies", in Goldstream Lake. Bubbles released from tinies seeps are trapped beneath lake ice typically without lateral merging (similar to A-type bubbles). However, unlike individual A, B, C, and Hotspot seeps, which have a more focused point of release and sites with tightly clustered and/or coalesced ice bubbles (usually less than $0.8 \mathrm{~m}^{2}$ in area), tinies bubbles are typically found in patches that span several square meters. Most tinies seeps release bubbles throughout the winter (K. M. Walter Anthony, unpublished data). Preliminary measurements indicate that tinies seeps occupy approximately $1.4 \%$ of the area of Goldstream Lake and that including ebullition from tinies seeps would increase our estimate of total seep ebullition in Goldstream Lake by 2 to $9 \%$. We estimate that including these seeps in the model would result in a $2 \%$ increase in the amount of dissolved $\mathrm{CH}_{4}$ in Goldstream Lake during the ice-cover periods, although this estimate is uncertain due to a lack of constraints on our representation of tinies in the model. These results warrant further investigation and characterization of tinies seeps.

\subsection{Sensitivity analysis}

Because of the many approximations in the formulation of the model, its output often differed from measurements. These discrepancies informed the construction of additional modified versions of the model used to estimate uncertainties in our results arising from these approximations. The modifications in these versions are summarized in Table 1, and their results are discussed in detail in Appendix A. Our findings imply two key conclusions. (1) Secondary processes that influence the dissolved $\mathrm{CH}_{4}$ concentration in Goldstream Lake during the ice-cover periods, such as $\mathrm{CH}_{4}$ diffusion from bottom sediments and methanotrophy, do not appreciably affect the magnitudes of IBS emissions. (2) The magnitudes of $\mathrm{CH}_{4}$ emission and oxidation during spring ice-melt and summer open-water periods are not well constrained in the model, and further investigation of these processes is therefore necessary.

\subsection{Future climate change}

We constructed a "warmer climate" version of the model, in which air temperatures were increased uniformly by $5^{\circ} \mathrm{C}$, to simulate future climate change. The only processes in the model affected were ice growth and the closing of Hotspot seep sites to the atmosphere. In this version, freeze-up was delayed by 15 and 8 days in 2010 and 2011, respectively, and the average yearly maximum ice thickness was $12 \%$ less than in the baseline version. The resulting increase in total atmospheric emissions was driven primarily by a $7 \%$ increase in direct ebullition emissions arising from shorter ice-cover periods and fewer days on which Hotspots were closed (Fig. A1c). Less $\mathrm{CH}_{4}$ dissolved into the water column from ebullition seep sites despite slower ice growth, resulting in decreased diffusion and IBS emissions during the spring ice-melt periods (Fig. A1b). A greater proportion ( $85 \%$ vs. $82 \%$ ) of $\mathrm{CH}_{4}$ released annually from sediments reached the atmosphere than in the baseline version (Table 1). As we did not account for the temperature dependence of methanogenesis, our estimates of the increase in $\mathrm{CH}_{4}$ emissions due to warming are likely conservative.

\section{Conclusions}

We present a model of $\mathrm{CH}_{4}$ transport and emission processes in seasonally ice-covered lakes, focusing primarily on $\mathrm{CH}_{4}$ dissolution from bubbles trapped beneath lake ice and IBS emissions. Close agreement between the model's output and our field measurements suggests that our model accurately represents many of these processes in Goldstream Lake and other thermokarst lakes.

IBS emissions constituted $8 \%$ of total annual emissions from Goldstream Lake during the 2-year study period. This quantity is primarily determined by ebullition and lake ice growth; it is insensitive to the amount of dissolved $\mathrm{CH}_{4}$ because the water column $\mathrm{CH}_{4}$ concentration is typically undersaturated relative to concentrations in bubbles. On an annual basis, a majority of $\mathrm{CH}_{4}$ in ebullition bubbles in the model is released directly to the atmosphere, unimpeded by lake ice. Methanotrophy determines the extent to which lake ice reduces net atmospheric $\mathrm{CH}_{4}$ emissions. In the model, the magnitudes of methanotrophy during the winter and summer periods are constrained by measurements of dissolved gases. The magnitude of spring methanotrophy was not well constrained due to uncertainties in the timing of $\mathrm{CH}_{4}$ release from trapped ebullition seep sites, the rate of wateratmosphere gas exchange, and the possible induction period of methanotrophy. The amount of dissolved $\mathrm{CH}_{4}$ subject to methanotrophy during spring ice melt is significant $(21 \%$ of $\mathrm{CH}_{4}$ released annually by diffusion and ebullition from the sediments of Goldstream Lake), so further investigation is needed to reduce this source of uncertainty in calculated $\mathrm{CH}_{4}$ emissions. Our model indicates that seasonal lake ice increases the amount of $\mathrm{CH}_{4}$ consumed by methanotrophs by facilitating $\mathrm{CH}_{4}$ dissolution from ice-trapped bubbles prior to encapsulation. Therefore, shorter ice-cover seasons and less black ice growth simulated in a warmer climate will likely increase $\mathrm{CH}_{4}$ emissions from northern lakes. The model's predictions for a warmer climate scenario could be further refined by including the effects of projected changes in precipitation on lake ice dynamics, particularly as they relate to the opening of Hotspot seep sites. 


\section{Appendix A: Sensitivity analyses}

\section{A1 $\mathrm{CH}_{4}$ diffusion from sediments}

The rate of $\mathrm{CH}_{4}$ diffusion from sediments in the model is uncertain because it was calculated from measurements in Vault Lake (Sect. 2.2.10), which exhibits greater seep ebullition activity than Goldstream Lake (Sepulveda-Jauregui et al., 2014b), likely because it is a younger thermokarst lake. This suggests the greater availability of substrate for methanogenesis (Kessler et al., 2012) in Vault Lake and therefore greater sediment diffusion rates. Furthermore, the diffusion rate in Goldstream Lake likely exhibits significant spatial variability, due to differences in substrate availability between its thermokarst and non-thermokarst zones, and temporal variability, due to seasonal variation in sediment temperature, which also influences methanogenesis rates (Whalen, 2005).

We constructed a "less diffusion" version of the model, in which the diffusion rate from sediments was 5 times less than in the baseline version, which resulted in a marginal decrease in the modeled amount of dissolved $\mathrm{CH}_{4}$ in the water column throughout the study period (Fig. 8a). This difference was not substantial because dissolution from trapped bubbles comprised $87 \%$ of the dissolved $\mathrm{CH}_{4}$ sources during the ice-cover periods in the baseline version (Fig. 12). Methanotrophy during the summer periods was considerably reduced (Fig. A1b), and a greater proportion ( 86 vs. $82 \%$ in the baseline version) of $\mathrm{CH}_{4}$ released from bottom sediments reached the atmosphere (Table 1).

Due to lower dissolved $\mathrm{CH}_{4}$ concentrations throughout the winter and spring in the less diffusion version, $0.4 \%$ more $\mathrm{CH}_{4}$ diffused into the water column from trapped bubbles. Because the maximum $\mathrm{CH}_{4}$ concentration in Goldstream Lake is generally significantly less than the saturation concentration calculated from the $\mathrm{CH}_{4}$ concentration within trapped bubbles, the magnitudes of bubble dissolution and IBS emissions are insensitive to the diffusion rate from sediments and other processes that affect the dissolved $\mathrm{CH}_{4}$ concentration. It may be possible to estimate ebullition and IBS emissions for lakes similarly undersaturated in dissolved $\mathrm{CH}_{4}$ using only information about lake ice and ebullition dynamics.

\section{A2 Lake ice thickness}

Although the model exhibits good agreement with measured total ice thicknesses, it does not agree as closely with measured white and black ice thicknesses during the ice-cover period (Fig. 5). These measurements are more uncertain than those of total ice thickness due to error associated with observers looking through narrow auger holes in winter for differences in ice color. We constructed two additional versions of the model in which calculated black ice thickness matched the upper and lower extremes of the range of our measurements and the total ice thickness matched measure-

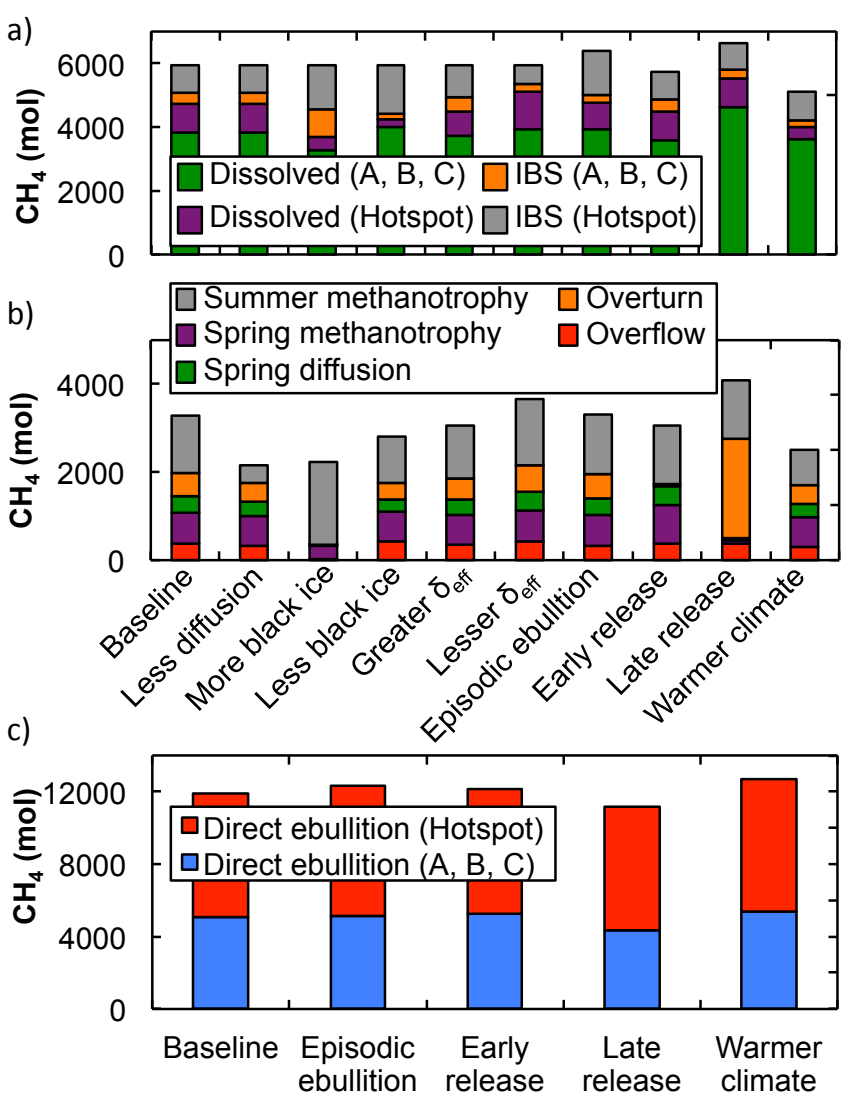

Figure A1. Mean yearly quantities of $\mathrm{CH}_{4}$ involved in various processes in the model, as calculated by the versions of the model described in Sects. 3.4 and 3.5 and Table 1. The magnitude of winter methanotrophy is constant among all versions because it is limited by the amount of $\mathrm{O}_{2}$ dissolved in the water column at the time of freeze-up. The magnitude of summer diffusion emissions is also constant because it is calculated from measurements of surface $\mathrm{CH}_{4}$ concentrations.

ments (Fig. A2). The snow density was fixed at either 300 or $100 \mathrm{~kg} \mathrm{~m}^{-3}$, resulting in "more black ice" or "less black ice", respectively, due to the associated changes in snow conductivity and snow depth. In the baseline version, the average snow density was $180 \mathrm{~kg} \mathrm{~m}^{-3}$.

In the more black ice version, flooding events (Sect. 2.3.2) were less frequent, resulting in less white ice growth and a $97 \%$ reduction in flooding emissions. At A, B, and C ebullition seep sites, more $\mathrm{CH}_{4}$ was encapsulated by ice and $14 \%$ less $\mathrm{CH}_{4}$ dissolved out of trapped bubbles (Fig. A1a). The magnitude of IBS emissions from A, B, and C seep sites was 2.5 times greater than in the baseline version. The opposite was true of results from the less black ice version.

\section{A3 Diffusively controlled layer thickness}

Setting the effective thickness of the diffusively controlled layer, $\delta_{\text {eff }}$, to 0.15 and $0.35 \mathrm{~mm}$ in the model of $\mathrm{CH}_{4}$ dissolution from submerged chambers (Sect. 2.2.7) yielded 

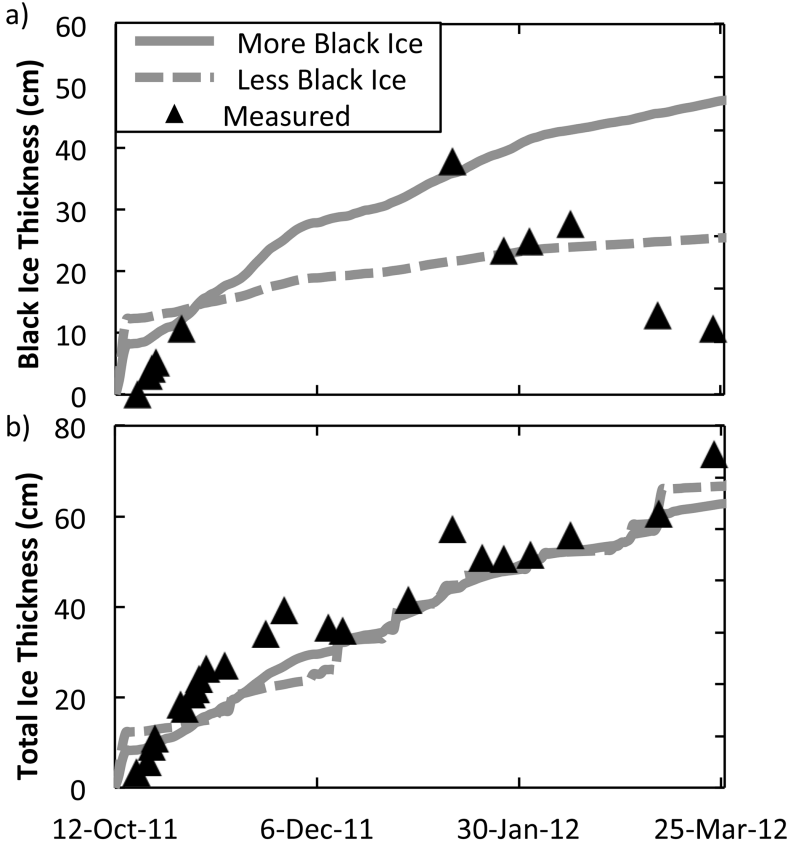

Figure A2. Measured and calculated black (a) and total (white and black, (b) ice thicknesses from the "more black ice" and "less black ice" versions of the model. Snow density was fixed in each version at 300 and $100 \mathrm{~kg} \mathrm{~m}^{-3}$, respectively.

reasonable fits to measured volumes and $\mathrm{CH}_{4}$ concentrations for both trials (Fig. 4), so these values were used in two additional versions of the model. At $\delta_{\text {eff }}=0.35 \mathrm{~mm}$ ("greater $\delta_{\text {eff"), }}$ " \% less $\mathrm{CH}_{4}$ dissolved into the water column from bubbles, which resulted in greater IBS emissions and less emission of dissolved $\mathrm{CH}_{4}$ during the spring ice-melt period (Fig. A1). The opposite was true for results from the "lesser $\delta_{\text {eff }}$ " version $\left(\delta_{\text {eff }}=0.15 \mathrm{~mm}\right)$. Eighty-three and $81 \%$ of $\mathrm{CH}_{4}$ reached the atmosphere in the greater and lesser $\delta_{\text {eff }}$ versions, respectively (Table 1 ).

\section{A4 Methane emissions during spring melt}

The model does not include biological processes that consume or produce $\mathrm{O}_{2}$ during the spring ice-melt period, which could significantly impact the magnitude of $\mathrm{CH}_{4}$ oxidation during this period. Furthermore, the timing of the release of trapped gas represented in the model may differ from reality due to the paucity of field observations of this timing. Consequently, the magnitudes of $\mathrm{CH}_{4}$ diffusion to the atmosphere and methanotrophy during the spring ice-melt periods in the model are uncertain. In the baseline version of the model, the amount of $\mathrm{CH}_{4}$ that dissolves into the water column from ebullition seep sites and sediments during the winter and spring periods, minus the amount oxidized during the winter periods, represents $21 \%$ of the total $\mathrm{CH}_{4}$ budget for Goldstream Lake. Methanotrophs consume $17 \%$ of this dissolved $\mathrm{CH}_{4}$ during the spring and summer peri- ods. Michmerhuizen et al. (1996) found that an insignificant portion of $\mathrm{CH}_{4}$ dissolved in Minnesota and Wisconsin lakes is oxidized during spring ice melt. If we similarly assumed no methanotrophy during the spring ice-melt periods in the model, spring diffusion emissions would increase by a factor of 2.8 and total atmospheric emissions during the study period would increase by $4.3 \%$.

We constructed two versions of the model ("early release" and "late release"), in which gas trapped at A, B, and C seep sites was released to the atmosphere on the first or last day of the ice-melt periods, respectively, to evaluate the impact of uncertainties in our release rate functions (Sect. 2.3.4). In the late release version, 4.4 times more $\mathrm{CH}_{4}$ dissolved from trapped bubbles during the spring ice-melt periods than in the baseline version, resulting in decreased IBS emissions from non-Hotspot seep sites and increased overturn emissions (Fig. A1). Total emissions during the spring ice-melt periods were $26 \%$ greater than in the baseline version, and $85 \%$ of $\mathrm{CH}_{4}$ released from bottom sediments throughout the study period reached the atmosphere (Table 1). Results from the early release version did not differ as much from the baseline version (Fig. A1) because the maxima of our release rate functions occurred close to the beginning of the spring icemelt period. These findings suggest that the timing of bubble release during the spring-ice melt period can significantly impact spring $\mathrm{CH}_{4}$ emissions and that further investigation is needed to reduce this source of uncertainty in our results.

\section{A5 Summer $\mathrm{CH}_{4}$ diffusion emissions}

There is a significant degree of uncertainty associated with our estimate of the magnitude of diffusion emissions during the open-water periods in the model, as we did not include the effect of wind speed on the rate of $\mathrm{CH}_{4}$ diffusion to the atmosphere, and we used measurements of the surface $\mathrm{CH}_{4}$ concentration in 2012 to calculate the diffusion rate in 2011 (Sect. 2.3.5). Diffusion emissions during the summer openwater period constitute a relatively small proportion $(9 \%)$ of total calculated $\mathrm{CH}_{4}$ emissions from Goldstream Lake during the study period. At most, summer diffusion emissions could increase by a factor of 2 (in which case no $\mathrm{CH}_{4}$ is consumed by methanotrophy during the open-water periods). In this case, summer diffusion emissions would constitute $16 \%$ of total emissions, but the magnitudes of IBS and direct ebullition emissions would remain unchanged. 


\section{Appendix B}

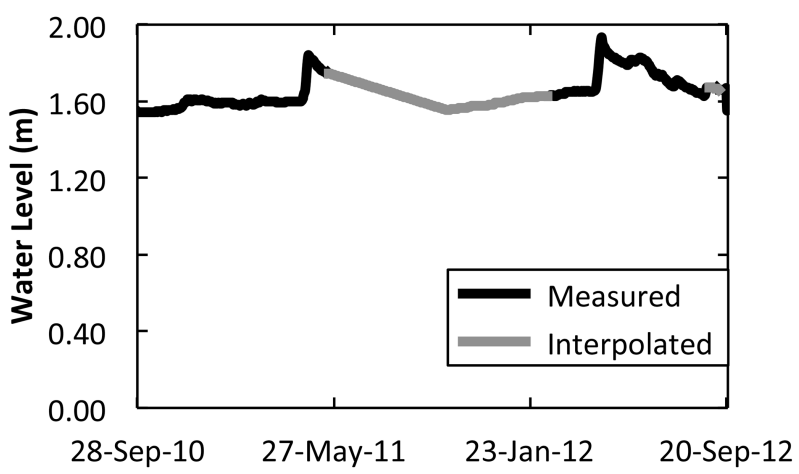

Figure B1. The water level in Goldstream Lake, as calculated from measurements of hydrostatic pressure on the lake bottom or as interpolated from precipitation measurements when pressure measurements were unavailable.

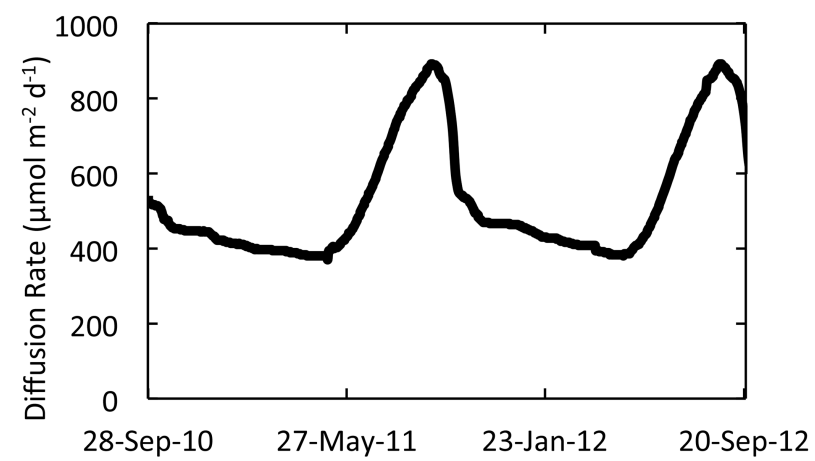

Figure B2. The rate of $\mathrm{CH}_{4}$ diffusion from the sediments of Goldstream Lake applied in the model during the study period, calculated as described in Sect. 2.2.10. The methanogenic rate increases as the temperature of surficial sediments increases, causing the observed annual cycle in the diffusion rate.

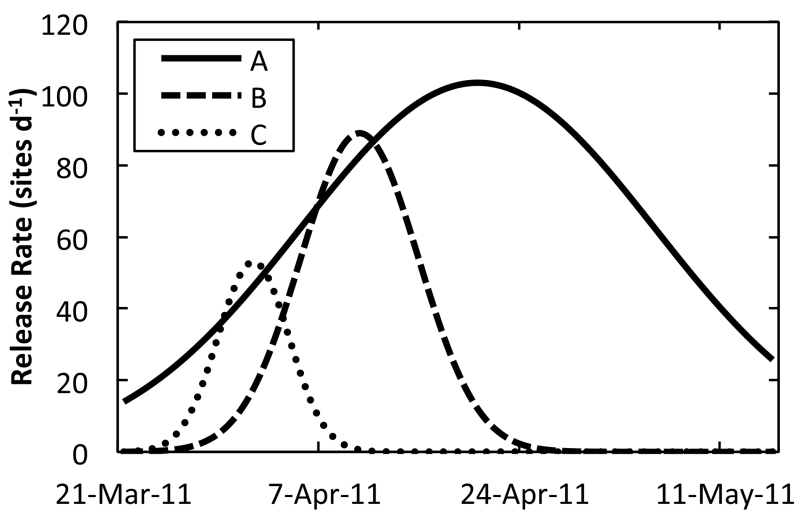

Figure B3. The rates at which sites in each ebullition class were opened to the atmosphere during the 2011 spring melt period, as informed by field observations. Rates for the 2012 spring melt period followed the same general pattern. The peak release rate of $\mathrm{C}$ seep sites occurred before those of A and B seep sites because a greater volume of encapsulated gas was observed at C seep sites. The total area beneath each curve is equal to the number of seeps of each type observed in Goldstream Lake. 
Author contributions. K. M. Walter Anthony conceived this study. S. Greene designed the model, developed the model code, and performed the simulations and data analysis with significant input from all co-authors. S. Greene and K. M. Walter Anthony wrote the manuscript. K. M. Walter Anthony, A. Sepulveda-Jauregui, and K. Martinez-Cruz were responsible for the field and lab experiments. All authors commented on the composition of the manuscript.

Acknowledgements. We thank Amy Strohm for measurements of snow and ice thickness, dissolved gas, temperature, ice-bubble mesocosms, and late-winter bathymetry. Dragos Vas, Laura Brosius, Laurel McFadden, Casey Pape, Odin Miller, Prajna Regmi, Allen Bondurant, Joanne Heslop, Melanie Engram, and Peter Anthony also assisted with field- and lab work. Christopher Swingley provided climate data from the NWS Co-Op site in Goldstream Valley. Peter Anthony conducted GIS analysis. Martin Jeffries and Frederic Thalasso provided input on the model's design. Melanie Engram and Martin Jeffries provided useful comments on the manuscript. This work was supported by the DOE grant no. DE-NT0005665, NASA Carbon Cycle Sciences grant no. NNX11AH20G, the NASA Astrobiology Institute's Icy Worlds node, and NSF grant nos. 0732735 and 1107892.

Edited by: V. Brovkin

\section{References}

Adams, E. E., Priscu, J. C., Fritsen, C. H., Smith, S. R., and Brackman, S. L.: Permanent ice covers of the McMurdo Dry Valley Lakes, Antarctica: Bubble formation and metamorphism, in: Ecosystem Dynamics in a Polar Desert: The McMurdo Dry Valleys, Antarctica, edited by: Priscu, J. C., American Geophysical Union, Washington, D. C., USA, 281-295, 2013.

Ashton, G. D. (Ed.): River and Lake Ice Engineering, Water Resources Publications, Highlands Ranch, Colorado, USA, 1986.

Bastviken, D., Cole, J., Pace, M., and Tranvik, L.: Methane emissions from lakes: Dependence of lake characteristics, two regional assessments, and a global estimate, Global Biogeochem. Cy., 18, GB4009, doi:10.1029/2004GB002238, 2004.

Bastviken, D., Cole, J. J., Pace, M. L., andVan de Bogert, M. C.: Fates of methane from different lake habitats: Connecting wholelake budgets and $\mathrm{CH}_{4}$ emissions, J. Geophys. Res., 113, G02024, doi:10.1029/2007JG000608, 2008.

Bastviken, D., Tranvik, L. J., Downing, J. A., Crill, P. M., and Enrich-Prast, A.: Freshwater methane emissions offset the continental carbon sink, Science, 331, p. 50, doi:10.1126/science.1196808, 2011.

Bender, M. and Conrad, R: Effect of $\mathrm{CH}_{4}$ concentrations and soil conditions on the induction of $\mathrm{CH}_{4}$ oxidation activity, Soil Biol. Biochem., 27, 1517-1527, 1995.

Bergmann, M. A. and Welch, H. E.: Spring meltwater mixing in small arctic lakes, Can. J. Fish. Aquat. Sci., 42, 1789-1798, 1985.

Boereboom, T., Depoorter, M., Coppens, S., and Tison, J.-L.: Gas properties of winter lake ice in Northern Sweden: implication for carbon gas release, Biogeosciences, 9, 827-838, doi:10.5194/bg9-827-2012, 2012.

Bohren, C. F. and Beschta, R. L.: Snowpack albedo and snow density, Cold Reg. Sci. Technol., 1, 47-50, 1979.

Broecker, W. S. and Peng, T. H.: Gas exchange rates between air and sea, Tellus, 26, 21-35, 1974.

Browman, L. G.: Channels in ice, in: Advanced concepts and techniques in the study of snow and ice resources, Santeford, edited by: Santeford, H. S. and Smith, J. L., Monterey, California, USA, 2-6 December 1973, 224-234, 1974.

Burn, C. R.: Tundra lakes and permafrost, Richards Island, western Arctic coast, Canada, Can. J. Earth Sci., 39, 1281-1298, 2002.

Casper, P., Maberly, S. C., Hall, G. H., and Finlay. B. J.: Fluxes of methane and carbon dioxide from a small productive lake to the atmosphere, Biogeochemistry, 49, 1-19, 2000.

Cole, J. J. and Caraco, N. F.: Atmospheric exchange of carbon dioxide in a low-wind oligotrophic lake measured by the addition of $\mathrm{SF}_{6}$, Limnol. Oceanogr., 43, 647-656, 1998.

Duguay, C. R., Flato, G. M., Jeffries, M. O., Ménard, P., Morris, K., and Rouse, W. R.: Ice-cover variability on shallow lakes at high latitudes: model simulations and observations, Hydrol. Process., 17, 3465-3483, 2003.

Dunfield, P. F., Liesack, W., Henckel, T., Knowles, R., and Conrad, R.: High-affinity methane oxidation by a soil enrichment culture containing a type II methanotroph, Appl. Environ. Microb., 65, 1009-1014, 1999.

Engram, M., Walter Anthony, K., Meyer, F. J., and Grosse, G.: Characterization of L-band synthetic aperture radar (SAR) backscatter from floating and grounded thermokarst lake ice in Arctic Alaska, The Cryosphere, 7, 1741-1752, doi:10.5194/tc-7-17412013, 2013.

Fancy, S. G. and White, R. G.: Energy expenditures by caribou while cratering in snow, J. Wildlife Manage., 49, 987-993, 1985.

Gash, J. H. C.: A note on estimating the effect of a limited fetch on micrometeorological evaporation measurements, Bound.-Lay. Meteorol., 35, 409-413, 1986.

Hamilton, T. D., Craig, J. L., and Sellmann, P. V.: The Fox permafrost tunnel: a late Quaternary geologic record in central Alaska, Geol. Soc. Am. Bull., 100, 948-969, 1988.

Hemmingsen, E.: Permeation of gases through ice, Tellus, 11, 355359, 1958.

Holocher, J., Peeters, F., Aeschbach-Hertig, W., Kinzelbach, W., and Kipfer, R.: Kinetic model of gas bubble dissolution in groundwater and its implications for the dissolved gas composition, Environ. Sci. and Technol., 37, 1337-1343, doi:10.1021/es025712z, 2003.

Huttunen, J. T., Alm, J., Liikanen, A. Juutinen, S., Larmola, T., Hammar, T., Silvola, J., and Martikainen, P. J.: Fluxes of methane, carbon dioxide and nitrous oxide in boreal lakes and potential anthropogenic effects on the aquatic greenhouse gas emissions, Chemosphere, 52, 609-621, 2003.

Intergovernmental Panel on Climate Change (IPCC): Climate Change 2013: The Physical Science Basis, Cambridge University Press, Cambridge, United Kingdom and New York, USA, 1535 pp., 2013.

Jakkila, J., Leppäranta, M., Kawamura, T., Shirasawa, K., and Salonen, K.: Radiation transfer and heat budget during the ice season in Lake Pääjärvi, Finland, Aquat. Ecol., 43, 681-692, 2009. 
Kanevskiy, M., Shur, Y., Fortier, D., Jorgenson, M. T., and Stephani, E.: Cryostratigraphy of late Pleistocene syngenetic permafrost (yedoma) in northern Alaska, Itkillik River exposure, Quaternary Res., 75, 584-596, 2011.

Kankaala, P., Taipale, S., Nykänen, H., and Jones, R. I.: Oxidation, efflux, and isotopic fractionation of methane during autumnal turnover in a polyhumic, boreal lake, J. Geophys. Res., 112, G02003, doi:10.1029/2006JG000336, 2007.

Keller, M. and Stallard, R. F.: Methane emission by bubbling from Gatun Lake, Panama, J. Geophys. Res., 99, 8307-8319, 1994.

Kelly, C. A. and Chynoweth, D. P.: The contributions of temperature and the input of organic matter in controlling rates of sediment methanogenesis, Limnol. Oceanogr., 26, 891-897, 1981.

Kessler, M. A., Plug, L., and Walter Anthony, K.: Simulating the decadal to millennial scale dynamics of morphology and sequestered carbon mobilization of two thermokarst lakes in NW Alaska, J. Geophys. Res., 117, G00M06, doi:10.1029/2011JG001796, 2012.

Kling, G. W., Kipphut, G. W., and Miller, M. C.: The flux of $\mathrm{CO}_{2}$ and $\mathrm{CH}_{4}$ from lakes and rivers in arctic Alaska, Hydrobiologia, 240, 23-36, 1992.

Lidstrom, M. E. and Somers, L.: Seasonal study of methane oxidation in Lake Washington, Appl. Environ. Microb., 47, 12551260, 1984.

Liikanen, A., Huttunen, J. T., Valli, K., and Martikainen, P. J: Methane cycling in the sediment and water column of mid-boreal hyper-eutrophic Lake Kevaton, Finland, Arch. Hydrobiol., 154, 585-603, 2002.

Liston, G. E. and Sturm, M.: Winter precipitation patterns in arctic Alaska determined from a blowing snow model and snow-depth observations, J. Hydrometeorol., 3, 646-659, 2002.

Lofton, D. D., Whalen, S. C., and Hershey, A. E.: Effect of temperature on methane dynamics and evaluation of methane oxidation kinetics in shallow Arctic Alaskan lakes, Hydrobiologia, 721, 209-222, 2014.

Mackay, J. R.: Disturbances to the tundra and forest tundra environment of the western Arctic, Can. Geotech. J., 7, 420-432, 1970.

Martinez-Cruz, K., Sepulveda-Jauregui, A., Walter Anthony, K. M., and Thalasso, F.: Latitudinal and seasonal variation of aerobic methane oxidation in Alaskan lakes, Biogeosciences, in preparation, 2014.

Mattson, M. D. and Likens, G. E.: Air pressure and methane fluxes, Nature, 347, 718-719, 1990.

Michmerhuizen, C. M., Striegl, R. G., and McDonald, M. E.: Potential methane emission from north-temperate lakes following ice melt, Limnol. Oceanogr., 41, 985-991, 1996.

Muhs, D. R. and Budahn, J. R.: Geochemical evidence for the origin of late Quaternary loess in central Alaska, Can. J. Earth Sci., 43, 323-337, 2006.

Nye, J. F.: The geometry of water veins and nodes in polycrystalline ice, J. Glaciol., 35, 17-22, 1989.

Péwé, T. L.: Quaternary geology of Alaska, United States Geological Survey Professional Paper 835, United States Government Printing Office, Washington, D. C., USA, 145 pp., 1975.

Phelps, A. R., Peterson, K. M., and Jeffries, M. O.: Methane efflux from high-latitude lakes during spring ice melt, J. Geophys. Res., 103, 29029-29036, 1998.

Reyes, A. V., Froese, D. G., and Jensen, B. J. L.: Permafrost response to last interglacial warming: Field evidence from non- glaciated Yukon and Alaska, Quaternary Sci. Rev., 29, 32563274, 2010.

Rudd, J. W. M. and Hamilton, R. D.: Methane cycling in a eutrophic shield lake and its effects on whole lake metabolism, Limnol. Oceanogr., 23, 337-348, 1978.

Sasaki, M., Imura, S., Kudoh, S. Yamanouchi, T., Morimoto, S., and Hashida, G.: Methane efflux from bubbles suspended in icecovered lakes in Syowa Oasis, East Antarctica, J. Geophys. Res., 114, D18114, doi:10.1029/2009JD011849, 2009.

Schulz, S., Matsuyama, H., and Conrad, R.: Temperature dependence of methane production from different precursors in a profundal sediment (Lake Constance), FEMS Microbiol. Ecol., 22, 207-213, 1997.

Sepulveda-Jauregui, A., Hoyos-Santillan, J., Martinez-Cruz, K., Belmonte-Izquierdo, Y., Walter Anthony, K. M., Casper, P., and Thalasso, F.: Eutrophication exacerbates potential methane production and consumption response in lake ecosystems to warming, Environ. Sci. Technol., in preparation, 2014a.

Sepulveda-Jauregui, A., Walter Anthony, K. M., Martinez-Cruz, K., Greene, S., and Thalasso, F.: Methane and carbon dioxide emissions from 40 lakes along a north-south latitudinal transect in Alaska, Biogeosciences Discuss., 11, 13251-13307, doi:10.5194/bgd-11-13251-2014, 2014b.

Smith, L. K. and Lewis Jr., W. M.: Seasonality of methane emissions from five lakes and associated wetlands of the Colorado Rockies, Global Biogeochem. Cy., 6, 323-338, 1992.

Stepanenko, V. M., Machul'skaya, E. E., Glagolev, M. V., and Lykossov, V. N.: Numerical modeling of methane emissions from lakes in the permafrost zone, Izv. Atmos. Ocean. Phys., 47, 252 264, 2011.

Sturm, M., Holmgren, J., König, M., and Morris, K.: The thermal conductivity of seasonal snow, J. Glaciol., 43, 26-41, 1997.

Tang, K. M., McGinnis, D. F., Frindte, K., Brüchert, V., and Grossart, H.-P.: Paradox reconsidered: Methane oversaturation in well-oxygenated lake waters, Limnol. Oceanogr., 59, 275-284, 2014.

Van Bodegom, P., Goudriaan J., and Leffelaar P.: A mechanistic model on methane oxidation in a rice rhizosphere, Biogeochemistry, 55, 145-177, 2001.

Walter, K. M., Zimov, S. A., Chanton, J. P., Verbyla, D., and Chapin III, F. S.: Methane bubbling from Siberian thaw lakes as a positive feedback to climate warming, Nature, 443, 71-75, 2006.

Walter, K. M., Chanton, J. P., Chapin III, F. S., Schuur, E. A. G., and Zimov, S. A.: Methane production and bubble emissions from arctic lakes: Isotopic implications for source pathways and ages, J. Geophys. Res., 113, G00A08, doi:10.1029/2007JG000569, 2008.

Walter Anthony, K. M. and Anthony, P.: Constraining spatial variability of methane ebullition seeps in thermokarst lakes using point process models, J. Geophys. Res., 118, 1-20, 2013.

Walter Anthony, K. M., Vas, D. A., Brosius, L., Chapin III, F. S., Zimov, S. A., and Zhuang, Q: Estimating bubble emissions from northern lakes using ice-bubble surveys, Limnol. Oceanogr. Meth., 8, 592-609, 2010.

Wania, R., Ross, I., and Prentice, I. C.: Implementation and evaluation of a new methane model within a dynamic global vegetation model: LPJ-WHyMe v1.3.1, Geosci. Model Dev., 3, 565-584, doi:10.5194/gmd-3-565-2010, 2010. 
Whalen, S. C.: Biogeochemistry of methane exchange between natural wetlands and the atmosphere, Environ. Eng. Sci., 22, 73-94, 2005.

Wilhelm, E., Battino, R., and Wilcock, R. J.: Low-pressure solubility of gases in liquid water, Chem. Rev., 77, 219-262, 1977.

Williams, G. P.: Water temperature during the melting of lake ice, Water Resour. Res., 5, 1134-1138, 1969.

Woolf, D. K. and Thorpe, S. A.: Bubbles and the air-sea exchange of gases in near-saturation conditions, J. Mar. Res., 49, 435-466, 1991.
Yamamoto, S., Alcauskas, J. B., and Crozier, T. E.: Solubility of methane in distilled water and seawater, J. Chem. Eng. Data, 21, 78-80, 1976.

Zimov, S. A., Voropaev, Y. V., Davydov, S. P., Zimova, G. M., Davydova, A. I., Chapin III, F. S., and Chapin, M. C.: Flux of methane from north Siberian aquatic systems: Influence on atmospheric methane, in: Permafrost Response on Economic Development, Environmental Security and Natural Resources, NATO Science Series 2, 76, edited by: Paepe, R. and Melnikov, V. P., Kluwer Academic Publishers, Dordrecht, Netherlands, Boston, Massachusetts, USA, 511-524, 2001. 